研究論文

\title{
明末清初以前の中国庭園における太湖石について
}

\section{The Taihu Rocks in Chinese Gardens before the 17th Century}

外村 中*

Ataru SOTOMURA

\begin{abstract}
摘要 : 太湖石は，今日の中国庭園を最も特色付けている些か奇怪にも見える石のことである。本稿は， 太湖石が今日のように利用されるようになったのは, 比較的時代が浅いらしいことを指摘し, 今日の 太湖石の庭園のみをもって中国の古庭園を梌討することは，必ずしも適切ではないと考えられるわけ を示す。
\end{abstract}

\section{はじめに}

中国の庭園と云えば, ほとんど誰しもが奇 怪な形態をした庭石が置かれているのを想像 するだろう。そして，そのような庭石の最も 代表的なものが太湖石であるということは， 造園の専門家にとっては, すでに周知のこと であろう "。言い換えれば, 太湖石の庭園こ そ今日の中国庭園であるといっても言い過ぎ ではない。

ところで, 太湖石により複雑に構成された 今日の中国庭園は, 今日我々が普通に考える ところの日本庭園とその様式を明らかに異に している。どうもこのためか, 日本庭園にお ける中国の庭園の直接の影響は，あまり検討 されていないのが事実のようである゙”。特に 石を用いてつくられた日本庭園の代表的様式 である枯山水の成立に関しての論考を見るに， 中国の山水画の影響に関しては語られるのに， なぜか, 同時代あるいは先行する時代の中国 庭園との直接の比較検討はほとんどなされて いない感がある。日本において枯山水が成立 した当時，すなわち十三世紀から十四世紀に かけて，あるいは，それ以前の中国の庭園が， 今日の中国庭園と同様な様式を持つものであっ たことが証明されれば問題はない。そうなれ ば，枯山水を語る時，中国庭園の直接の影響 を検討する必要もないだろう。

しかしながら，万が一，中国の太湖石の庭 園が，今日我々が目にすることができる中国 庭園と様式を異にしていたらどうであろうか。 あるいは，中国の庭園は，かつて今日の日本 庭園のような様式をもっていたかもしれな ( $^{3)}$ 。

実際, 今日中国に残る太湖石の庭園遺構は, ほとんどすべて, 後世特に近年の大幅な改修 を受けている。また，古くてもせいぜい明代 （1368-1661）末頃の様式を伝えるものが, ほんのわずか部分的に残るに過ぎないようで ある。したがって，太湖石の庭園が，明末清
初（十七世紀頃）以前において，どのような ものであったのかは, 必ずしも明らかではな いのである。

ちなみに，比較的古い様式を部分的に伝え ると考えられる庭園遺構としては, 清初（康 熙年間：1662-1722）のものとして，蘇州の 耦園, 無錫の寄暢園, また, 明末（萬暦： 1573-1620) のものとして, 上海の豫園, 嘉 定の秋霞園などが，わずかにあげられる程度 である゙”。

そこで, 本稿では, 太湖石が, かつて特に 明末清初以前において如何に愛好され庭園に 用いられていたかを概観し，中国の庭園はか つてはどのようなものであったのかを検討し てみたい。

本稿は, 次のように構成する。

1.太湖石に関する代表文献資料名をあげる。

2.太湖石とは如何なる石かを説く文献資料 の内容を検討する。

3.太湖石の産地について検討する。

4.太湖石の何処に魅力があったのかを検討 する。

5.太湖石の流行の始まりについて検討する。

6. 史上最も有名な艮䓂の太湖石について検 討する。

7.太湖石が, 実際, 如何に流行したかを確 認する。

8. 結論。

ところで, 本稿では, 浅学にもかかわらず, 敢えて出来る限り多くの資料の訳出を試みた。 その方が, 中国に扮ける太湖石愛好の状況を より詳細に理解できると考えたからである。 不適切なところもあろうかと恐れているとこ ろである。

\section{1. 太湖石資料}

ここで，太湖石に関する明末清初（十七世 紀頃）以前の代表的な資料名をあげておきた w。
先ず，宋代（北宋（960-1127）／南宋（ 1127-1279)）以前の資料索引としては, 范 成大 (1126-1193) の『点郡志』巻二十九が, また, 宋代以降のものとしては, 稲若水( 1667-1717）等による『庶物類纂』石属巻六 十六が有用である。そして, 『呉郡志』なら びに『庶物類筧」に引用されている資料に， さらに，太湖石に関するその他の代表的な資 料を併せ，人物名を優先して時代順に示せば， 大方次の通りになる。

1 ) 唐 (618-907), 白居易 $(772-846)$ の 『太湖石記」( 7 - (3)； 7 章の (3) 参照と いう意味である。その簓所に訳文を示し ている。以下に同じ。)

2 ) 唐, 白居易の『寄庭侍郎」

3 ) 唐, 白居易の『雙石』( 7 - (2) $)^{5}$ )

4 ) 唐, 白居易の『(太湖石 $) 」$

5 ) 唐, 白居易の『(太湖石)』(白居易には 太湖石と題する詩が二つある。

6 ）唐, 白居易の『感舊石上字」

7 ) 唐, 白居易の『楊六尚書留太湖石在洛下 借置庭中因對舉杯寄贈絶句」

8 ) 唐, 白居易の『牛相公宅太湖石（奉和思 黯相公以李蘇州所寄太湖石奇状絶倫因題 二十韻見示兼呈夢得)」

9 ) 唐, 白居易の『池上篇并序」

10）唐, 白居易の『池上作」

11）唐, 劉禹錫（772-842）の『和題姑蘇所 寄太湖石兼寄李蘇州(和牛相公題姑蘇所 寄太湖石兼奇李蘇州)』

12) 唐, 牛僧擩 $(779-847)$ の『題太湖石詩 序 (李蘇州遣太湖石奇状絶倫因題二十韻 奉呈夢得楽天)」 $(7-$ - (4) $)$

13）唐, 皮日休 (833-883?)『(太湖石)」

14）唐, 陸龜蒙（?-881）の『(太湖石)」

15）唐, 吳融（ca. 890）の『太湖石歌」

16）唐, 盧言（？）の『盧氏雜説」（5-(1)

17) 宋 (960-1279), 陶款 (d.ca. 1000)の 『清異録】

\footnotetext{
*ヴュルツブルク大学中国学研究所
} 
18) 宋, 胡宿 $(996-1067)$ の 『(太湖石 $) 』$

19) 宋, 陳洙 (1013-1061) の『太湖石賦并 序』

20) 宋, 方勺 (1066-?) の『伯宅編』(6(6)

21）宋, 杜綰（ca.1130）の『雲林石譜』(2)(1) $)^{6}$

22) 宋, 程俱 (1078-1144) の『太湖採石賦 (採不賦)』

23）宋, 程大昌 $(1123-1195)$ の『演繁露』 (註-27 : 註 27 参照。以下同じ。)

24) 宋, 范成大 $(1126-1193)$ の『呉郡志』 ( 2 -(2), 6-(5))

25) 宋, 范成大の『太湖石志』（2-3)，3(1))

26) 森, 張端義（1179-？）の『貴耳集』（6(11)

27）宋, 趙希鹄（ca.1240）の『洞天清禄 (集)』 $(2-(4))$

28）宋, 張添（ca.1180-1250）の『艮獄記』

29) 宋, 韋居安 (ca.1260) の『梅間詩話（梅 澗詩話)」

30) 宋, 周密 $(1232-1308)$ の『癸辛雜識』 $(6-14))$

31）『宋史』卷八十五 $(6-$ (1)), 卷四百七十 ( $6-(3))$

32) 宋, 常禁（?）の『宣和石譜』(6-9)

33）宋, 蜀僧祖考（？）の『宣和石譜』（6(8))

34）宋, 蜀僧祖秀（？）の『華陽宮記事』(6(7))

35）宋, 張邦基（？）の『墨荘漫録』（6-4)

36）宋，袁褧（?)『楓窗小覑』(6-(2))

37）撰者未詳の『漁陽公石譜』( 4 - (3))

38）宋, 漁陽公（？）の『漁陽石譜』（4-(2)

39）宋 (元), 陸友仁（?）の『研北雜志』

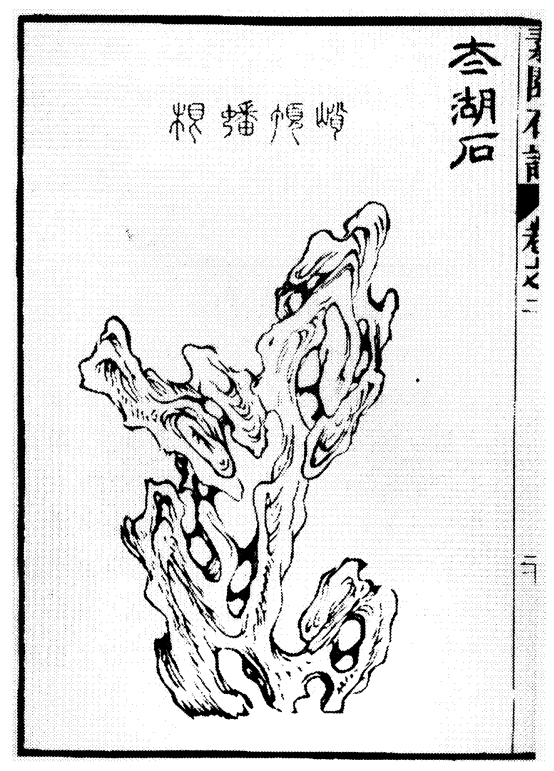

図 1 ) 太湖石図。(『素園石譜」巻二。)
(註一22)

40）元 $(1279-1367)$, 袁桷 (1267-1327) の 『澄懐録』

41) 元, 胡助 (ca.1330) の『秋堂湖石』

42) 明 (1368-1661), 高啓 (1336-1374) の 【太湖石】 ${ }^{8}$

43）明, 黄省曾 $(1490-1554)$ の『呉風録』 $(6-(10))$

44）明, 歸有光 $(1506-1571)$ の『秦國公不 記】

45）明, 朱國禎（d.1624）の『太湖石』

46) 明, 陳繼儒 $(1558-1639)$ の太平清話』 (註-24)

47）明, 謝肇淛（ca.1590）の『五雜組』(2 (5) $)^{9)}$

48）明，林有麟（ca.1600）の『素園石譜』

49) 明, 計成 (1582-?) の『園治」(2-6)

$50 ）$ 明, 文震亨 $(1583-1644)$ の『長物志』 $(2-(7))$

$51)$ 明, 張岱 $(1597-1689)$ の『陶庵夢憶】

52）明, 毛晉 (鳳苞) の (1598-1659) の

『海獄志林』( 4 - (1)

53) 明, 曹昭（？）の『格古要論』

54）明,『大明一統志』

55）明, 姑蘇志』

56) 清 $(1662-1911)$, 李漁 (1611-?) の 「間情偶寄』 $(4-\text { (4) })^{12}$

57) 清, 姜紹書 (?) の『韻石庳筆談』(6(13) )

58）清, 顧震濤（？）の『呉門表隱』(6-12)

59) 清, 『江南通志』

60) 清, 『湖州府志』

61) 清, 『呉縣志』

\section{2.太湖石とは如何なる石か}

太湖石とは, 太湖 (江蘇, 浙江両省にわた
る湖で，あるいは，洞庭湖とも云われる）周 辺で採れる石灰岩で，現在，中国庭園を代表 する庭石であることは，すでに周知の通りで ある(図 1)。

ところで，太湖石には，大きく分けて，水 中より採れるものと地上でとれるものの二種 類がある。水中より採れるもののほうが, す ぐれていて, 石の表面に，窪みや穴が多い。 この篗みや穴を, 弾窩, あるいは弾子曧とい う。中国の造園技術書として知られる明の計 成の『園治』（2-6)）によれば，太湖の洞 庭西山の簏の消夏湾という入江でとれるもの が, 最もすぐれていたという（図 2 )。

一方, 地上で採れるものは, 早石と呼ばれ る。不思議な形をしてはいるが, 乾燥してい て光沢がない。しかしながら，太湖の洞庭西 山の東簏に位置する公山よりは，なかなかす ぐれたものが採れたようである（図 2 )。北 宋 (960-1126) の徽宗 (r. 1100-1125) は, 艮獄という極めて大きな假山を, 当時の都, 開封（河南省）につくらせたことで有名だが, その時，ひときわ際立った太湖石が，艮獄へ 向かう道の傍らに据えられたという。実は, その太湖石が画山で採られたものであったと いうことが,『墨荘漫録』(6-(4))に記され ている。なおここ艮獄の太湖石に関しては, 6 章で詳しく検討する。

ところで，以下に再び検討するが，太湖石 は，八世紀後半から九世紀前半頃より流行し はじめたようである。白居易の『太湖石記』 (7-3)によれば，太湖石は，九世紀前半 にはすでに献上品にもなっており，石上に文 字を記すこともはじめられている。そして, 十二世紀の艮获の造成は, 太湖石大流行の引 金になったようである。また, 『呉郡志』(2(2)）によれば，十二世紀ごろには，地上で採
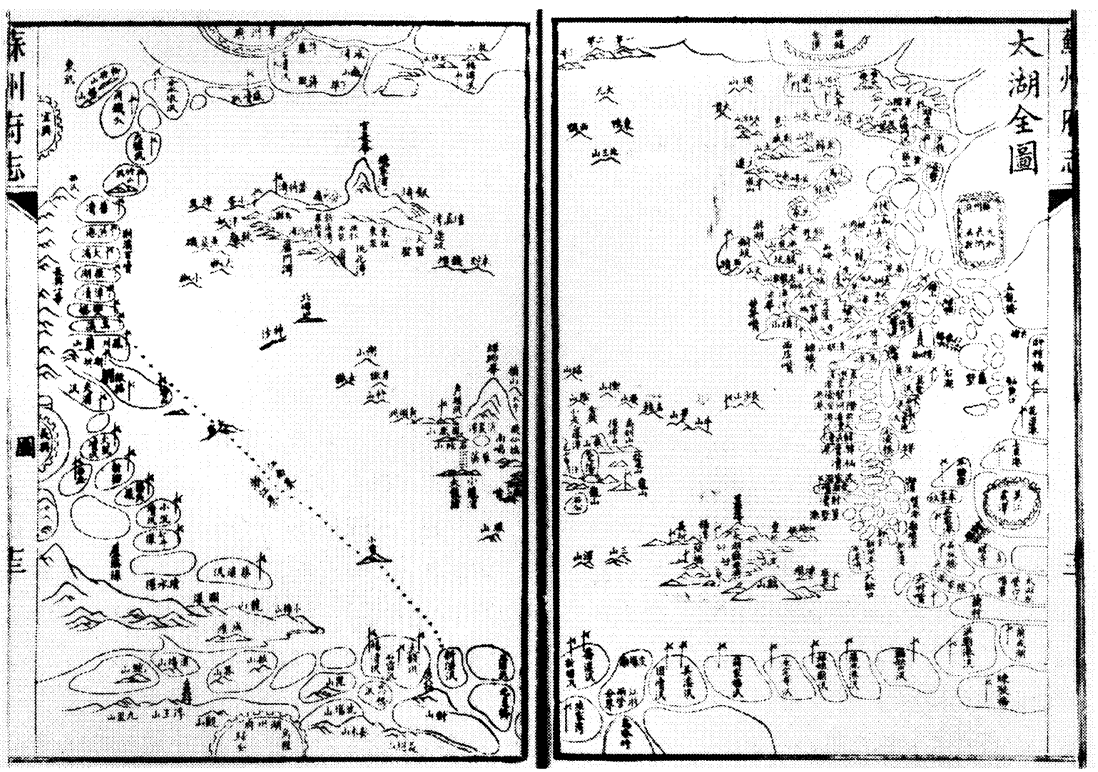

図 2 )『蘇州府志』太湖全図。中央やや下にある島が洞庭西山。 その西部分に消夏湾，その東部分に雨山が見える。 
れる太湖石に手を加えて, 水中より採れる太 湖石に似せることが始まっている。また，そ れは，なかなかの商売になっていたらしい。 『洞天清禄集」（2-(4)，7-(1)）によれば, 十三世紀までには，太湖石を黒く彩色する技 術も登場していたようである。実は,これは, 当時あるいは太湖石より愛好されていたとも 考えられる霝壁石の偽物として売るための手 段でもあったようである。

さて，太湖石とは如何なる石かを説いた文 献は多いが, その中でも, 最も明快なもので, かつ, 最も古い資料に属するものとして先ず あげられるのが, 宋の杜綰の「雲林石譜』の 太湖石の説明である。実は, よく知られてい る『園治」の太湖石の説明は,これをほほそ のまま引用したものに過ぎない。園治』(2(6)）の説明は, 消夏湾で採れる太湖石が一番 すぐれていたということ, また, 当時すでに 採石過剩で, 太湖石の数が少なくなってしまっ ていたということの二点を,『雲林石譜」の 内容に加えただけのものである。ちなみに，

『雲林石譜」によれば，太湖石とは大方次の ような石である。

(1) 宋の杜綰の『雲林石譜』上巻。太湖石。 “平江府 (今の江蘇省尅縣) の太湖石は, 洞庭湖（すなわち太湖）の水中より採れる。 太湖石は, 堅くて (堅), 光沢があり (潤), 中空になっていて (欤空), 穴が開いてお り (穿眼), 美しくて (宛転), 高くそびえ (嶮), 不思議な形 (怪)をしている。色は, 白いもの, 青黒いもの, 水色をしたものが ある。筋目が縦横に走っており，触が入这 んでいて,まるで, 彫刻したようである。 石の表面には，全体的に，寉みや穴が多い。 思うに，風や波に洗われてできたものだろ う。この寉みや穴を, 弾子䆚という。吒く と, 微かにひびく。採石する時, 人は, 鉬 と䠛をもって, 水中深くもぐる。かなり困 難な作業である。石のよいものを見極めて 切り取る。石の穴に大きな鋼を貫き通し， それを木の台を組み立てた大きな舟の上に， 引き上げる。引き上げた石の中には，あま り良くないものが僅かにある。そんな時に は，彫ったり，磨いたりして手を加える。 そして, 再び, 水中に沈める。久しくする と，風や波に洗われて，石に自然に筋目が 入ったように見えるようになる。最も高い もので, 高さが三から五尺（約 9.2-15.4 $\mathrm{m}$ ) ある。低いものでは, 十数尺（15尺は 約 $4.6 \mathrm{~m}$ ）をこえない。中には，一尺（約 $30.7 \mathrm{~cm})$ 余りのものもある。ただ，欄のそ ばに立てたり，假山をつくったり，庭園 （園林）や塀の内に置き並べたりするのが よい。甚だすぐれた眺めとなる。しかしな がら，机の飾りになるような小さくてすぐ れたものは，あまりない。”
尚, 以下に, 太湖石とは如何なる石かを説 くその他の代表的な資料を時代順に紹介する が, その内容は, 『雲林石譜』の内容とほほ 同様である。したがって、『雲林石譜』の内 容を知っていれば, 以下の資料は, ほとんど 無視して構わないかもしれない。しかしなが ら, そういえるのは, それぞれの資料を, 筆 者は以下のように解釈したからである。

\section{(2) 宋の范成大の「呉郡志」巻二十九。}

“太湖石は, 洞庭西山で採れる。水中よ り採れるものがすぐれている。太湖石は， 長い年月, 大波に洗われて, あまねく中空 になっている(嵌空)。石の表面は, 麗し く鮮やかで (鱗鱗), くほみができている。 このようなくほみを弾䆚という。これも， 波に洗われてできたものである。潜水夫が, 綱を伝わって, 水中に潜っていき, 太湖石 を穿ち採る。これは, 極めて困難な作業で ある。太湖石は, 温かく(温), 光沢があ り(潤), 不思議な形をしている(奇巧)。 吒くと, 鐘馨（楽器の名）のように響く。 唐代より爱好されている。山で採れるもの を旱石という。これも,また, 不思議な形 をしている(奇巧)。しかしながら，枯れ ていて（枯）, 光沢がない（不潤）ので, はなはだ貴重であるというわけではない。… 近年, 土大夫（官僚）たちで, 石を爱好す る者が多い。そのため, 山に住んでいる者 達が, 旱石を彫刻して, 向こうが透けて見 える（玲瓏）ような穴をつくったり，石の 表面を削って, 弾窩に似せたくはみや穴を つけるようになった。何も知らない者に売 ると, 高い值で売れることもあるようであ る。すぐれた形をしてはいないが, 青白く 玉のような材質で, 石碑を作ったり，階段 に用いたりするのによいものが，太湖中の 画山（洞庭西山東簏）で採れる。光沢があっ て清らかで (塋潔)，ものが鏡のように映っ て見え (可鑑)，黄金や珠玉のように，堅 くて (堅), 潤いがある(潤)。霆山の太湖 石も，(石碑や階段に用いられる石として) 天下第一である。程俱が賦に記したのは， まさに,この石である。”

\section{(3) 宋の范成大の「太湖石志』(説郛」鸟}

$$
\text { 九十六。) }
$$

“太湖石は, 西洞庭で多く採れる。大波 に洗われて, 中空となり（嵌空）, 潤いが あり (浸濯), 光り輝いている (光塋)。な かには, 珪瓚（酒器の名）のように黒い光 沢があったり (縝潤), 武器のように鋭かっ たり (廉檅)，峰のように䇤えていたり (需)，屏風や障子のように連なっている (列）ものもある。また，油を塗ったよう に滑らかなもの（滑，，漆を塗ったように 青黒いもの（䵢), 人や獣や鳥のような形 をしたものもある。爱好者は, これを集め
て, 庭園（苑直庭除）に飾っている。”

“太湖石は, 水中より採れるものがすぐ れている。長い年月，大波に洗われて，中 空になっている(啱空)。石の表面は, 麗 しく鮮やか (鱗鱗) で, くほみができてい る。これを弾浻という。これもまた，波に 洗われてできたものである。吒くと，磬 (楽器の名)のように響く。”

\section{(4) 宋の趙希鹄の「洞天清禄集』怪石辯。}

“太湖不は, 平江 (江蘇省吳縣) の太湖 で採れる。土地の者が採っている太湖石に は，大きなもので, 高さが, 一から二丈 (約 3.1-6.1m) あるものもある。まず, 彫刻し, そして, 急流の中にさらして, 水 に打たせる。久しくすると，自然にできた もののようになる。煙でくすぶったり，色 を付けたりすると，色は黒くなる。吒くと， 微かに響く。假山を作るのによい。”

\section{(5)明の謝㲤淛の「五雜組」巻三。}

“洞庭西山で, 太湖石が採れる。生地は 黒く, 白い筋目が入っている。高さは，八 尺から一丈（約 $2.5 \mathrm{~m}$ から $3.1 \mathrm{~m}$ ) を超え る。峯が筻え(峯整), 穴が開いている (窟穴)。そのうえ，天然の趣があるので， （それを見ると）坐ったままいろいろなと ころに行っているような気になる。その值 段は,よいものは百金, 覀いものでも十数 金を下らない。園池中に，必ずあるべきも のであるが, わが閩中（福建）では，特に 得難い。思うに, 山々に阻まれて, 海運で なければ取り寄せられないからである。”

(6) 明の計成の『園冶」巻三。五, 選石。 太湖石。

“蘇州府の洞庭山の水辺で, 太湖石は採 れる。消夏湾で採れるものが, 一番よい。 太湖石は, 堅くて (堅), 光沢があり (潤), 中空になっていて(嵌空), 穴が開いてお り (穿眼), 美しくて (宛転), 高くそびえ (嶮), 不思議な形 (怪)をしている。色は, 白いもの, 青黑いもの, 僅かに青黑いもの がある。筋目が縦横に走っており，雅が入 込んでいて，まるで彫刻したようである。 石の表面には，全体的に，窪みや究が多い。 思うに，風や波に洗われてできたものだろ う。この窪みや穴を, 弾子䆚という。叨く と, 微かにひびく。採石する時, 人は, 鈻 と鏨をもって, 水中深くもぐる。石のよい ものを見極めて切り取る。石の穴に大きな 鋼を貫き通し，それを木の台を組み立てた 大きな舟の上に，引き上げる。太湖石は， 高く大きなものがすぐれている。思うに， 軒や堂の前に立てたり，高い松の木や珍し い草木の下に置くとよい。假山を作ったり， 庭園（園林）に並べ置いたりすれば，実に すぐれた眺めとなる。昔より今に至まで, 採石すること久しいので，今では，ますま 
す少なくなった。”

(7) 明の文震亨の『長物志」巻三。品石, 太湖石。

“太湖石は, 水中より取れるものがすぐ れている。長い間, 大波に激しく洗われて, あまねく中空になり（空石）。各々の面は， 穴が開いていて，向こうが透けて見える (玲瓏)。山で採れるものを早石という。枯 れていて (枯), 光沢がない (不潤), そこ で, 弾窝（水中より採れる太湖石に見られ るくほみや穴）に似せたくほみや穴をつけ る。久しくすれば，手を加えた跡は，まっ たくなくなり，美しく見える（雅観）。呉 中 (江蘇省呉縣) で流行している假山は, すべて,この石を用いている。また，太湖 石の小さなものが, 昔より, 太湖の中に沈 んでいる。漁師が, これを網にかけて採っ ている。露璧石や英石にたいへんよく似て いるが、太湖石は吒いてもあまり響かない。 "

\section{3. 太湖石の産地名勝}

太湖石の特に有名な産地は, 太湖中の洞庭 西山と呼ばれる島である（図 2 )。その島の 中でも, 水中の採石場として消夏湾が, 地上 の採石場として画山が有名であったことは前 章でも述べたところである。尚, 最近の報告 によれば，太湖石は国家の保護するところと なり，採石は許されなくなっているようであ $る^{(3)}$ 。

ところで, 今で云えば太湖石名勝観光案内 のようなものを，すでに宋代に范成大が『太 湖石志」に記している。現在の状況を筆者は 知らないが, 当時有名な太湖石の名勝が偲ば れて興味深い。とにかく, 太湖は単に庭石で ある太湖石の産地としてではなく，太湖石に よる自然の名勝としても有名だったのである。 以下に, 『太湖石志』の該当箇所を紹介する。 尚, 基本的には, 太湖石の産地名勝は, 洞庭 西山にあったと理解しておけばよいようであ る。

\section{(1) 宋の范成大の『太湖石志』(『説䣋』马 九十六。)}

“宜山石。(覀山は, 洞庭西山の東簏に 位置する。この石は, 堅くて, 光沢があ る。石碑や土台石や柱や礎に用いるとよい。 一名, 旱石という。『蘇州志」はいう。玉 のように堅くて, 光沢がある。これを吒く と響く。碑を彫るには，実にこれが一番よ い石である。これを用いて階段を作るのも よい。世にまた稀なものである。 小洞庭。(洞庭西山の) 龍山（龍頭山）の 南にある。七十二の峰が㑨えているように 見える。綺里の東南五里 (約 $2.8 \mathrm{~km}$ ), 圻村 の山道に, 水に臨んで, ひとつの石がある。 青緑色をしていて, 周囲は, 二十餘歩（約
$31 \mathrm{~m})$ ある。その上には, 七十二の峰があ る。よって, そう名付けられている。

雞距石。(洞庭西山の) 山の麓にある。鳥 が立ち止まっているかのように見える石で ある。

神鉦石。(洞庭西山の) 林屋洞の中にある。 鐘と鼓のように, 叨くと, 澄んで調子よく 響く石である。

石板。(洞庭西山の) 石公山の麓にある。 平らで, 人が数人座ることができる石であ る。

鷹領石。縹絳峰（洞庭西山の最高峰）の頂 上にある。䳡のように，荒々しく㔍えてい る石である。

元我石。霄漢領 (不明) の南にある。我の ように見える石である。

石室。(洞庭西山の) 龍頭山の近くにある。 大きな洞穴で，家のように見える。

龍舌石。新安保 (不明) の西にある。高く 鋭く䇤えた石である。

石壁。東洞庭（洞庭東山）の豐圻の南にあ る。屏風のように見える大きな石である。 唐代に柳毅という人物が, 木を三度唹いて 案内者を呼び, そして, 洞庭湖の龍宮にいっ たという話（李朝威の『柳毅伝』）の舞台 がここである。

仙人石。(洞庭東山の) 寒山の西岸にある。 仙人が，足を投げ出したり，足を組んだり して座った跡のようなものが, はっきりと ついた石である。

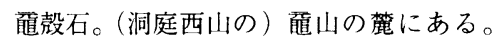
水面から，よろめきながら現われているか のように見える石である。船頭は，行き来 するに、この石に衝突しないように気を使つ ている。それゆえ，次のように云われてい る。東に兆殼石を, 西に兆山を見ながら, 二つの舟を網で連ねて，その間をゆっくり と通り過ぎるのがよいと。

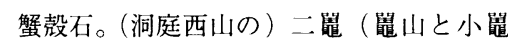
山）の南にある。逃殼石に似ているが，そ れよりも小さな石である。

龍林石。(洞庭西山の) 石公山の簏にある。 夢床のように見える石である。伝えに云う。 蛇のような石が, 半分その姿を現している。 また, 向こうには, 大艘の頭のような石が, ひそかに現われている。この二つの山（龍 頭山と仺山のことか) を見ながら舟を進め ると下には, 龍の寝床 (龍牀石) が沈んで いると。”

\section{4.太湖石のどこがよかったか}

太湖石を記した資料に当たると，大体にお いて, 堅い(堅), 光沢がある (潤), 中空に なっている(空), 穴が開いている(穿眼、 嚴岫)，向こうが透けて見える(玲瓏)，美し い(宛転, 雅観), 高く㑇えている (嶮, 峰
䇶)，不思議な形をしている（怪，奇巧）等 といった特徴が記されている。

では，そのどこがよかったのかは，次のよ うな怪石の評価基準を記した文献の内容によっ て理解されよう。

例えば, 清の李漁の『間情偶寄」によれば, 山石の美しさは，透（吻が縦横に走っている）, 漏（穴が開いていて，向こうが透けて見える）, 瘦（細く高く算えている）の三字をもって表 わされるという $(4-$-4) 。

また，次のような資料もある。

\section{(1) 明の毛晉 (鳳苍) の「海嶽志林」}

“相石（石の選び方）。米南宮（怪石趣 味で知られた米芳 $(1051-1107)$ は, 瘦

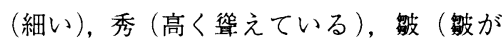
多いという意味か)，透（中空となり，向 こうが透けて見えるという意味かの四点 をもって, 石を選んだ。”

(2) 宋の漁陽公の『漁陽石譜】【説郛」鸟 九十六。)

“元章 (米蒂) は, 次の四点によって石 を選んだ。秀。瘦。雅（上品である）。透。 石の美しさを，すべて言いあててはいない が，大体その通りである。”

\section{(3) 撰者未詳の『漁陽公石譜』(『説郛」巻 十六。)}

“元章は，次の四点によって石を選んだ。 秀。瘘（瘦の誤りか）。嗉。透。石の美し さをすべて言いあててはいないが,だいた いその通りである。”

以上より, 石の堅さや色, 光沢などには, 特別な好みは見出だせないが, その他の形状 において, 太湖石が, 他の怪石より好みに適つ ていたということができよう。尚, その形状 を如何に解釈したかに関しては，太湖石を主 題に記した詩文の内容を検討しなければなら ないだろう。この点に関して，7章で代表的 な詩文として白居易の『雙石』と『太湖石記』, ならびに牛僧瓀の『李蘇州遣太湖石奇状絶倫 因題二十韻奉呈夢得楽天』を訳出紹介するの で, 参照してほしい ( 7 -(2)(3)(4))。

また，太湖石は，蘇州を中心とする地域の 産物である。蘇州は, 中国の歴史上, 経済文 化の一大中心ともいえる都市である。したがっ て, 蘇州文化の象徴としての太湖石の価値も 見落としてはならないだろう。

さらには, 北宋の徽宗の艮㺘造成以降, 特 に大型の太湖石が, 富や権力の象徵ともなっ ていたらしい (6 章を参照)。この点も太湖 石が愛好された理由としてあげられよう。

尚, 『間情偶寄」は, 中国における怪石評 価基準に関して最も詳しく述べた資料である と考えられるので, その内容は, 知っておく 必要があろう。

(4)【間情偶寄」巻九。山石第五。小山。 “山石の美しさは, 透, 漏, 瘦の三字を 
もって表わされる。(解が,) ここがあちら へと, あちらがここへと走っていて，(ま るで）道が通じているようなものを透とい う。石の表面に眼（のような穴）があって, それぞれの面から，向こうが透けて見える のを漏という。空に向かって切り立ち, 独 り高く䇤えていて寄り掛かるものがないの を瘦という。そして, 透と瘦は, 至るとこ ろにあってもかまわないが, 漏の甚だしい のはよろしくない。もし, 至るところに眼 があれば, まるで, 笔の中で焼きあげてい る焼き物に, 僅かばかりの気に入らぬとこ ろが見つかったが，葟の中にあるので，も はやどうしようもないのに似た気持ちにな る。ふさがっているかと思えば, 通じてい るように，たまたま，そこに眼があるよう なものがよい。細くて小さな山を作るとす れば，常に，頂を広くして，麓を狭くする 必要がある。根元の部分が大きかったら, たとえ美しい形をしていても，見るに足ら ない。石の眼は, 円いのはよくない。もし, それが，自然にできたものであっても，脇 に砕けた小石を貼りつけて, 尖った角を持 たせ，整った円にならないようにすべきで ある。”

\section{5. 太湖石はいつ頃から流行したか}

ここでは, 太湖石の流行のはじまりについ て少し詳しく見ておきたい。というのは，太 湖石の発見者は, 唐の白居易 $(772-846)$, すなわち白樂天であると明言する研究者があ るが，そうとは言い切れないのではなかろう かと筆者は考えるからである。

太湖石という言葉を記した文献資料として, 明らかに, 白居易以前に遡れるものは, 現在 のところ見当らないようである。また, 白居 易には『雙石』（7-(2)）という詩があり， そこに「当時の人は (その石を) 嫌って取ら なかった (時人嫌不取)」という句があるの で，これを太湖石を総じて嫌って取らなかっ たと解秎し, 白居易こそ太湖石の発見者であ るとするのが, 田治六郎の解釈である ${ }^{14)}$ 。尚, この解釈は, 下山重丸により, 『造園修景大
事典』にそのまま引かれている ${ }^{15)}$ 。

しかしながら, 白居易こそ太湖石の発見者 であるならば，白居易は中国文学の代表的な 人物でもあるので,この点に因んだなんらか の話が中国に残っていてもよさそうなはずだ が，そのような話を記したものは，少なくと も 1 章に示すような太湖石に関する代表的な 文献資料の中には見当らない。したがって, 白居易の『雙石』と題する詩にいう太湖石は, 単に白居易が個人的に手に入れた二つの太湖 石に関してのみ語っていると解釈したほうか 適切ではなかろうかと考えるのである。とに かく, 太湖石の流行の始まりは, 必ずしも明 瞭ではないのである。

ところで, 太湖石の流行のはじまりを記し た文献資料をみるに，

・『吳郡志』(2-(2)) は, 太湖石の流行 は唐代 (618-907) 以降とする。

『呉風録』(6-10) によれば, 太湖石 は, 吳中 (江蘇呉縣)においては, 宋代 に艮嶽という假山が造成されたころより 流行しはじめ, 明代までには，金持ちか ら貧乏人にまで広く流行していたという。 『五雑組』や『癸辛雜識』によれば,一 般に石は宋の宣和年間 $(1119-1125) に$ 艮獄が造成されたころより重んじられる ようになったという ${ }^{16)}$ 。

また, 笑い話として, 次のような話がある。

(1) 唐の盧言（?）の『盧氏雜説』（『佩文 韻府』巻百上。太湖石。)

“ある高官が太湖石を買い入れるため将 軍を浙西に派遣したところ, 将軍より次の ような手紙が届いたという。「ご希望の太 湖石, 虫食いだらけで,買うに堪えません。” これは, 中空となったり, 穴があいている ところが多い太湖石の特徴が, 唐代ではまた 必ずしも広くは知られていなかったことを示 していると考えてよかろう。

以上により, 太湖石は, 唐代特に白居易の ころ, すなわち八世紀後半から九世紀前半頃 より，太湖石という名称を以て知識人の間で 流行しはじめ, 宋の宣和 $(1119-1125)$ 年間 に艮嶽という假山が造成されて以降広く流行
するに至ったといえよう。

ついでだが, 七世紀頃の代表的な離宮であ る九成宮の遺址に，太湖石が転がっていると いったことを宋の蘇轍（1039-1112）が詩に 記している ${ }^{17)}$ 。ししここれが事実を伝えるも のであるとしたら，太湖石の流行の始まりを さらに一世紀ほど遡らせることが出来るわけ であるが, 惜しむらくは, その真偽のほどは 分からない。

また, 図 3 は, 九世紀後半に唐の孫位 (?) によって描かれた『七賢図』である。太湖石 と思われる怪石が描かれている。これは,太 湖石あるいは太湖石と思われる怪石を描いた 画像資料として, 最も古いものに属する。太 湖石の流行の始まり当時は，あるいは，この ように太湖石を幾つか庭園内に据え置く程度 が普通であったのかもしれない。7章で詳し く述べるが, 太湖石趣味で有名な白居易の庭 園にも，太湖石は僅かに数個据えられていた 程度であったようである。

\section{6. 艮嶽の太湖石}

中国における太湖石大流行のきっかけをも たらしたのが, 宋の徽宗（r.1100-1125）に よる艮崔の造成であったらしい。艮訔とは, 政和七年 (1117) より首都の開封の上清寶籙 宮の東に造られた周が十餘里 (約 $5.5 \mathrm{~km}$ ), 最 高峰の高さが九十歩 (約 $138.2 \mathrm{~m}$ ) に及ぶ大 規模な假山のことである ${ }^{18)}$ 。本来, 公式には 萬歳山とよばれたが, 宣和四年（1122）に一 通りの完成をみ, この時, 宮城の艮 (東北) に位置することから艮訜と改められたとも云 われている ${ }^{19)}$ 。艮嶽造成のため, 江南地方か ら奇花異草をはじめ多くの太湖石が集められ た。朱勔 (1075-1126) という人物を指導者 とするこれらの収集運搬に携わるもの達は, 世に花石綱とよばれその横暴は人々に恐れら れた。江南より開封におよぶ長距離の運搬は, 太湖石を世に知らしめることにもなった。ま た, 宣和五年 (1123) には, 太湖石の歴史上 もっとも有名な太湖石が, 洞庭西山東簏の詯 山で朱詯によって採石され開封に運ばれ艮獄 に向かう道の傍らに据えられている。そこで,

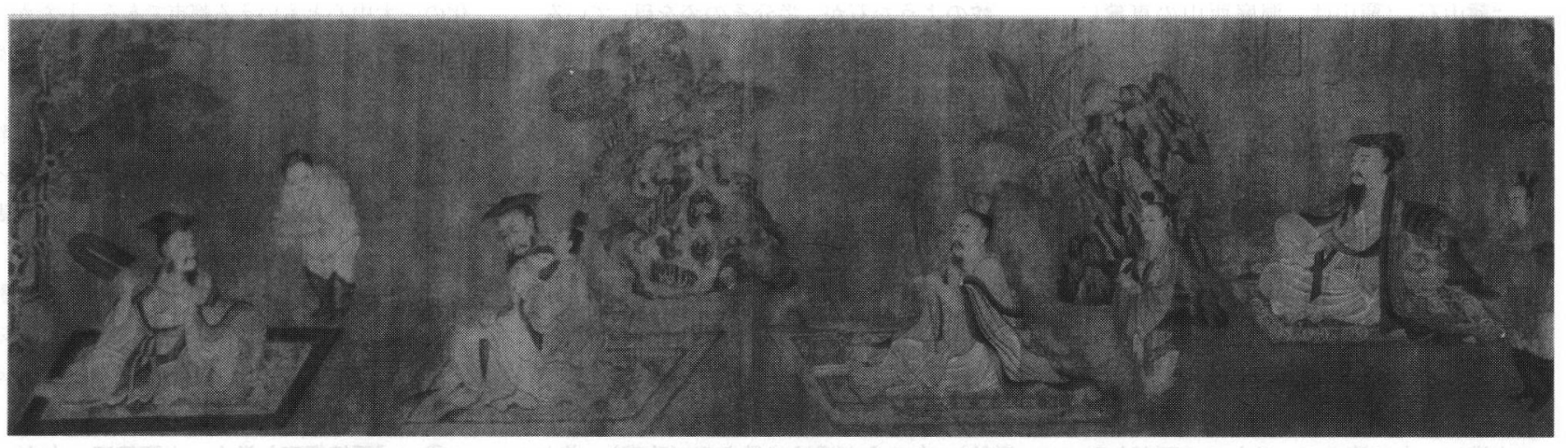

図 3 ) 孫位 ( 9 c後半) の『七賢図」。太湖石と思われる怪石が見られる。 太湖石流行の初期では, 太湖石の庭園はこの程度のものだったかもしれない。 
ここでは,この太湖石に関して少し詳しく検 討しておきたい。

先ず, 採石の時期に関しては,

・『宋史』巻八十五 $(6$ - (1) $)$ や楓窗小 牘」（6-2)）によれば, 宣和五年に, 採石したという。

大きさに関しては,

・『宋史』巻八十五 $(6$-1) や『楓窗小 牘」(6-(2) によれば, 高さならびに 幅は数丈 (五丈は約 $15.4 \mathrm{~m}$ ) という。

・『宋史」巻四百七十 ( 6 - (3) に には, 高 さ四丈 (約 $12.3 \mathrm{~m}$ ) という。

『墨荘漫録』(6-(4)) では, 高さは四 丈，幅はその半分という。

『華陽宮記事』( 6 - (7)), 蜀僧祖考の 『宣和石譜』(6-8)), 常森の『宣和石 譜」(6-9) は, 高さが六仞（約 12.9 $\mathrm{m}$ ), 幅が百圍（1 圍を 3 寸とすれば， 約 $11.1 \mathrm{~m}$ ) とする。

したがって，幅に関してはよく分から ないが，高さは $12 \mathrm{~m}$ 以上あったわけで ある。

採石の場所に関しては,

『墨荘漫録』(6-(4)) に, 茞山であっ たことが記されている。

爵位に関しては,

『迨郡志』などによると,この太湖石は 盤固侯という諸侯の位を徽宗より授けら れている (6-(5)(6)(7)(8)(9).

ところで, この太湖石はさらに徽宗より号 を賜ったとされるが，その号に関しては資料 により相違がある。筆者は, その号は神運昭 功敷慶萬年 (壽) であったのではなかろうか と考えているので，以下にその理由を整理し ておきたい。号に関する資料を見るに，

・『宋史』巻八十五は, 昭功敷慶神運石と する $(6-$ (1))。

『楓窗小牘』は, 敷慶神運石とする $(6-$ (2))。

『宋史』巻四百七十は, 神運昭功石とす る。( 6 -(3))。

『墨荘漫録』は, 神運昭功敷慶萬年之峰 とする (6-(4))。

、『華陽宮記事』は, 神運峰とする（6(7))。

・常禁の『宣和石譜』は, 神運と昭功は, 異なる太湖石の号であるとする (6-9)。 蜀僧祖考の『宣和石譜』は, 神運昭功と 敷慶萬壽を, 異なる太湖石の号とする $(6-8)$ 。

『素園石譜』は, 神運昭功と敷慶萬壽を, それぞれ異なる太湖石の号として，それ ぞれの想像図らしきものの図を付してい る(図 4 )。

さて,

『墨荘漫録』(6 - (4)) は, 神運昭功敷

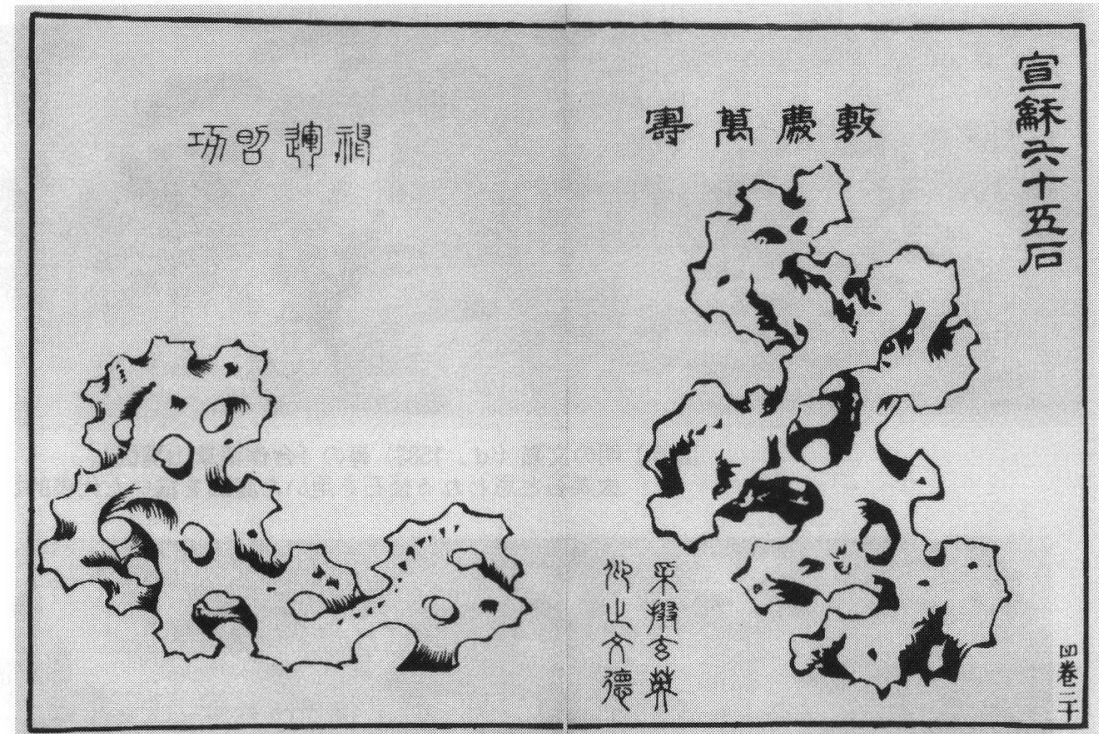

図 4 ) 『素園石譜」巻四。宣和六十五石。神運明功。敷慶萬壽。

慶萬年之峰を, 一つの太湖石とする。 『吳郡志』(6-5) や『伯宅編』( 6 (6)）によると, 『宋史』巻八十五（6(1)), 巻四百七十 (6-3) や『楓窗小 覑」(6-(2) にいう太湖石は, 明らか に一つの太湖石であると考えられる。

ということは, この太湖石の号は, 神運昭 功敷慶萬年（壽）であったのではなかろうか。 つまり, それぞれの資料が, 神運昭功敷慶萬 年 (壽) という号を略して記したと考えられ まいか。石譜の類より,むしろ正史である 『宋史」やその太湖石を直接目にしての記録 と考えられる『墨荘漫録』にできるだけ基づ くべきではなかろうか。したがって，『宣和 石譜』や『素園石譜』にいうように, 神運と 昭功を, あるいは, 神運昭功と敷慶萬壽を異 なる太湖石とするのは, 問題があろうと考え るのである。

ところで, 盤固侯に封じられ, 神運昭功敷 慶萬年 (壽) の号が授けられたらしい高さ四 丈 (約 $12.3 \mathrm{~m})$ のこの太湖石が, その後どう なったかに関しては, 今となっては知る由も ないようである。したがって, 史上名高いこ の太湖石を実際に目にすることは，もはやで きない。しかしながら，艮猫の造成のために どのような太湖石が集められたかを示す実例 が今でも残っているので, その姿を想像する ことができないわけでもない。現在, 蘇州市 第十中学にある瑞雲峰と呼ばれる太湖石が, その例である（図 5 )。その由来に関しては, 『呉門表隐』（6-12) は, 董邭陽（?）から, 徐氏の所有に帰したとし, 『韻石齋筆談』(6(13) は，もともと王陶 $(1020-1080)$ の別荘 にあったのが, 後に徐氏の所有に帰したとす る20)。惜しむらくは, 現在のところ, どちら が正しいかわからないようである。

また, 艮獄の太湖石を記す資料の内容から

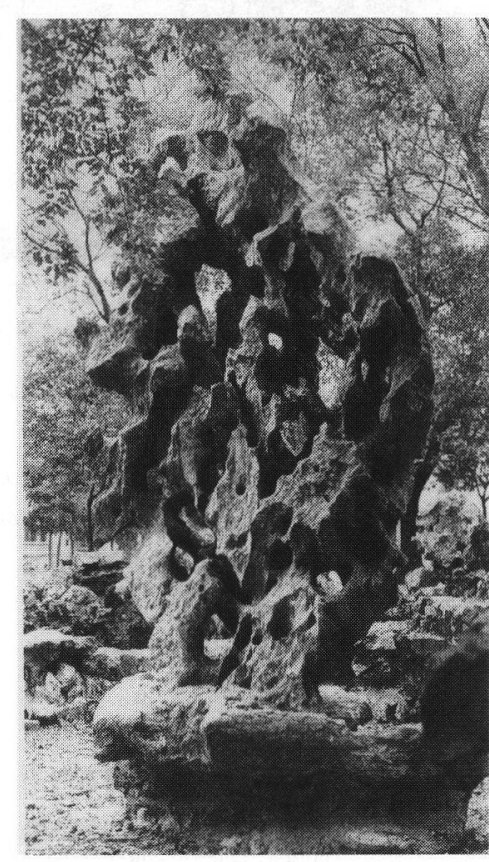

図 5 ) 瑞雲峰。

考えて，艮嶽の太湖石が世の注目を浴びたの は, その美しさもさることながら，高さ四丈 （約 $12.3 \mathrm{~m}$ ）というその大きさにも理由があっ たようである。おそらく，艮獄が造成された 当時では, 高さ四丈もある太湖石を庭園に据 えるということは信じがたいことであったの だろう。ところが, 時を僅かに移すこと南宋 （1127-1279）の時代, 時の権力者たちが, 艮 嘼の太湖石に大きさにおいても負けないほど の太湖石を手に入れていたことが,『癸辛雜 識』（6-14)）により知られる。これは, 大 型の太湖石が富や権力の象徵となっていたこ とを示すものと考えてよかろう。また，艮嗺 の太湖石は後に史上から姿を消すが,これは, 艮獄の太湖石と同等あるいはそれ以上のもの 


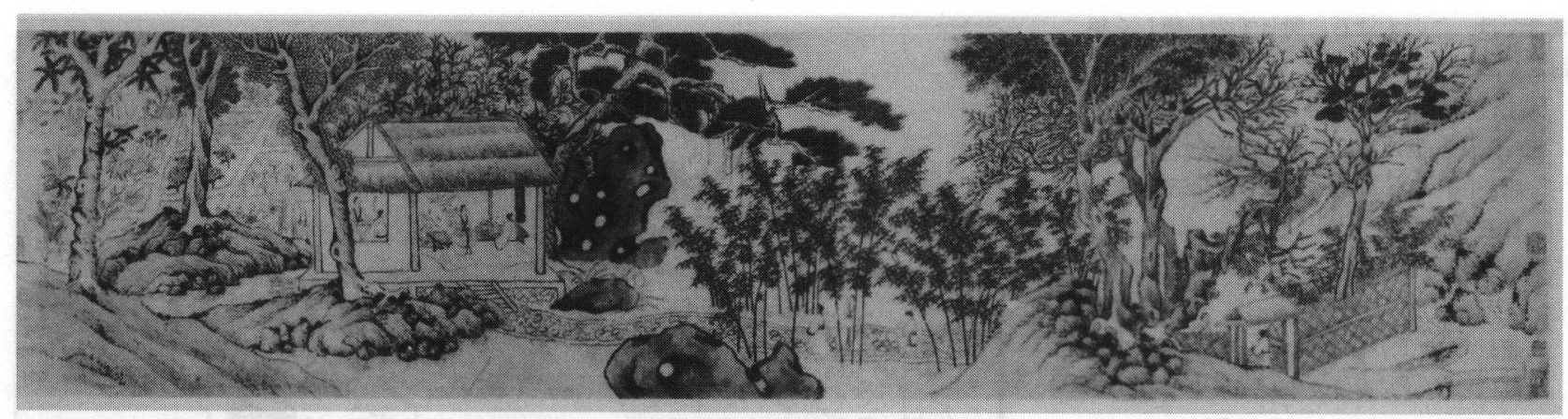

図 6 ) 明の文嘉 (d.1583) 等の『合作薬草山房図」。 太湖石と思われる怪石を用いた庭園を描いた代表的な作品である。

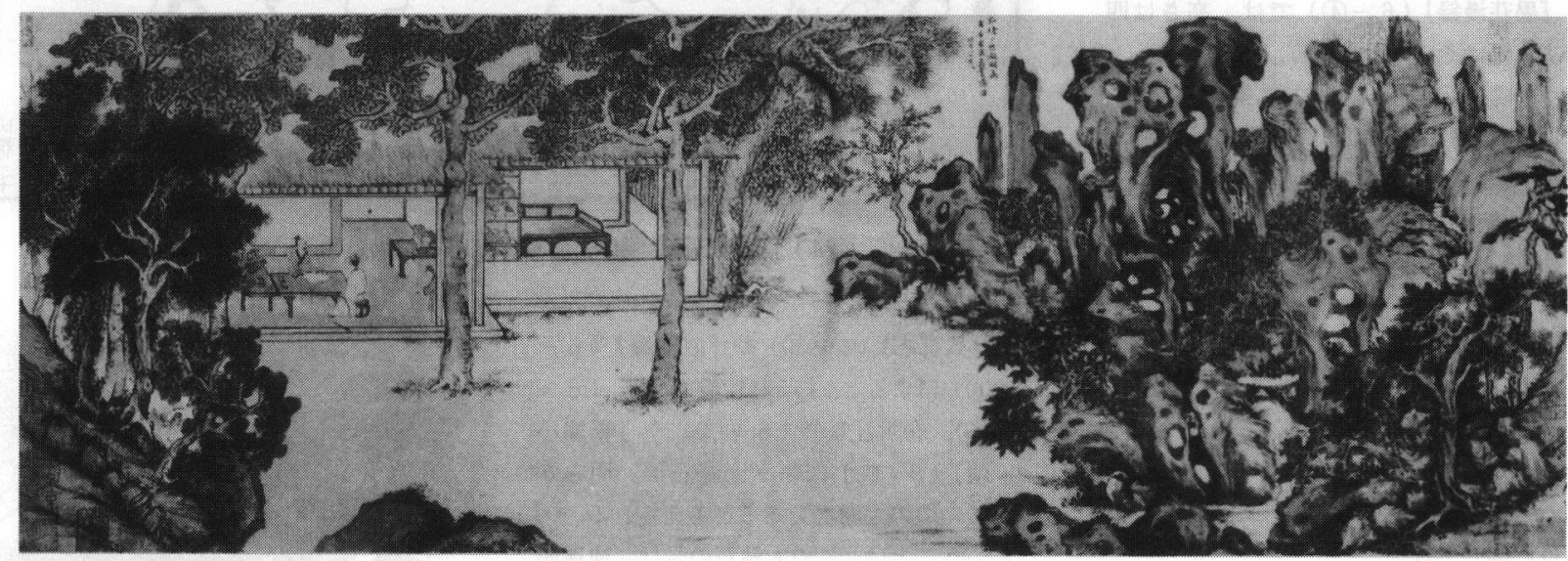

図 7 ) 明の文征明 (16C.) の『真賞齋眓」。

太湖石と思われる怪石を用いた庭園を描いた代表的な作品である。

が数多く登場したためでもあろうと考えられ まいか。

ついでだが, 艮孰の造成のため数多くの太 湖石が収集あるいは没収されたが，それを僅 かに遡る建中靖國元年（1101）にも，同じく 徽宗の命により, 江南地方に於いて大規模な 太湖石収集が行なわれたことが，程俱の 『(太湖) 採石賦」に記されている。それによ れば, 首都の開封の景霊西宮を造るために, 太湖の包山（洞庭西山）にて, 太湖石四千六 百を採石したという。

尚，以下に, 艮獄の太湖石に関する代表資 料の内容を詳しく紹介しておきたい。

(1)「宋史』巻八十五, 志三十八, 地理一。

“萬歳山艮啍。政和七年 (1117)，上清 寶籙宮の東に, 萬歳山を造りはじめた。周 が十餘里 $($ 約 $5.5 \mathrm{~km}$ ), 最高峰の高さが九十 歩 (約 $138.2 \mathrm{~m})$ あった。…宣和四年 (112 2), 徽宗は, 自ら『艮䜌記」を記した。山 が宮城の艮の方角にあったので, 艮猚といっ た。…宣和五年 (1123), 朱勖は太湖で石 を採った。高さと幅が, 数丈 ( 5 丈は約 15 . $4 \mathrm{~m})$ あった。大きな舟に乗せて，千人の 人夫に引かせた。運河を開き, 橋を断ち切 り，堰を破り，城門を壞して，その石を運 んだ。数か月かかって, やっと都に着いた。 徽宗は, その石に, 昭功敷慶神運石の号を 賜った。この年, はじめて, 燕の地を得た
(という縁起のよさに) 因んだのである。” (2) 宋の袁褧の「楓窗小牘』巻上。

以上(1)の宣和五年の記録と同じ内容が 見られる。ただし, 昭功敷慶神運石は, 敷 慶神運石と記されている。

(3)『宋史」巻四百七十, 列伝二百二十九、 位幸, 朱䣦。

“かつて, 太湖石を得た。高さは, 四丈 (約 $12.3 \mathrm{~m})$ あった。大きな軍船に乗せて, 数千人の人夫に引かせた。州や縣を通るに, 水門や橋を壊し, 城壁を崩し, その石を運 んだ。そうして, 都に至った。そして, そ の石は, 神運昭功石の名を賜った。”

(4) 宋の張邦基の『墨荘漫録』巻二。

“宣和癸卯 (五年), 平江 (江蘇省尅縣) の朱詯は, 太湖の㑇山で, 太湖石をとった。 高さ四丈 (約 $12.3 \mathrm{~m}$ ) 餘り, 幅はその半分 の太湖石がひとつ採れた。鮮やかで, 向こ うが透けて見え, 中空になっていて, 穴が たくさん開いていた。彫刻してできるよう なものではなかった。…二つの船をはじめ て造った。八千䋎という大金を費やして, その石は, 都に運ばれた。多くの時を費や したのに, 運河が浅く、また, その石があ まりに重かったので, 船は前に進むことが できなかった。そこで, 先ず, その石を絵 図に描いて報告した。徽宗皇帝は, その石 に, 神運昭功敷慶萬年之峰という名を賜る
旨を文章でお知らせになった。当時の人は, 誰しもが, その石を目にした。私は，ある 時,はじめて呉中（江蘇省尅縣）に行った おりにも，その石を目にしたものである。 ところが,この秋, その石が,なんと今や, 都 に運ばれ，艮䓂に置かれているのである。” (5) 宋の范成大の『呉郡志』巻二十九。

“宣和五年, 吳郡の人である朱洏は，大 きな軍船を造り,ひとつの太湖石をのせて, 都に運んだ。千人の人夫に担がせた。この 日, 人夫達は, それぞれ銀製の椀をいただ いた。また, 朱詯の四人の従者は, 皆, 官 位を授けられ，旗印と黄金で飾った帯を賜つ た。朱勔は, ついに, 威遠軍節度使となっ た。朱詯が運んだこの太湖石は, 盤固侯の 爵位を授けられた。

朱勔が誅せられると, 他の小さな太湖石 でままだ献上されていなかったものが，吳 郡の西の運河の両岸に残っていた。それら は, ことごとく, 張循王の家の所有となっ た。”

(6) 宋の方勺の『伯宅編」巻中。

以上(5) の前半と同じ内容が見られる。

\section{（7) 宋の蜀僧祖秀の『華陽宮記事」}

“西に宮門を開いている。華陽宮へ入る ための道は，馳道（開封にあった皇帝専用 道路）よりも広い。その道の左右には, 大 きな石があまねく林立している。全部で, 
百餘株ある。それは, 神運昭功敷慶萬壽峰 と名付けられている。他と異なり, 神運峰 は, 幅が百圍（1圍を 3 寸とすれば, 約 $11.1 \mathrm{~m}$ ), 高さが六仞 (約 $12.9 \mathrm{~m}$ ) ある。 盤固侯の爵位を賜っている。道の途中に置 かれている。石を集めて小さな建物 (小亭) を造り, その庇の下に, 神運峰はある。建 物の高さは, 五十尺（約 $15.4 \mathrm{~m}$ ) ある。”

（8）宋の蜀僧祖考の『宣和石譜』(説郛』 巻十六)

“神運昭功。敷慶萬壽。このふたつは, 最もすぐれている。他と異なり, 神運峰は, ...”以下は, (7)の内容と同じ。

(9) 宋の常森の『宣和石譜」(『説郛」马九 十六)

“神運。昭功。このふたつは，最もすぐ れている。他と異なり, 神運峰は, …以 下は, (7)の内容と同じ。

\section{(10) 明の黄省曾『呉風録」巻一。}

“朱詯は, 花石綱をはじめ, 天下に威厳 を示した。太湖石一つで, 多くの銀製の椀 を得た。彼の従者は, 官位を授けられ，ま た，黄金で造った帯を賜った。その石は, 盤固侯に封ぜられた。そして, 石を重ねて 艮獄が造られた。この時より今に至るまで, 呉中 (江蘇省呉縣) の富豪達は, 競って太 湖石を用いて, 不思議な形をした峰や奥深 い洞窟を造っている。多くの身分の高いも の達は, すばらしい太湖石を手に入れ, 彫 剂をほどこし，実に美しくしている。そし て, 珍しい花や木とともに，太湖石を用い て, すばらしい庭園（固）を作っている。 庶民や筫民に至っても，太湖石を用いて， 僅かばかりの假山（盆島）をつくって飾り としている。太湖石を集めることが, 熱狂 的になり，多くのお金が費やされている。 朱洏の子孫が, 虎丘 (江蘇省吳縣の西北の 山）の簏に住んでいる。今尚, 造園業（種 芸畳山）を営み，王侯の家に仕えている。 世に, 花園子と呼ばれている。彼らのうち で貧しいものは, 季節ごとに, 花を背負い
やって来て, 吳の町のなかを売り歩いてい る。農業はあまりしていないのである。” (11) 宋の張端義の『貴耳集」巻中。

“石は, 人のように話すことができるの である。…宣和年間に，艮猬が造られた。 朱勔が, 太湖石を献上した。その中に, 数 千人をしても動かせないものがあった。徽 宗皇帝は, 思い計っておっしゃられたそう である。「この石は, 官職と爵位を求めて いるにちがいない。」そこで, 徽宗皇帝は, その石を大将軍に封じられた。そして, 黄 金で飾られた帯を賜われ，それをその石の 上に置かせられたところ，石が動きだした。 これも, 石が人のように話した例である。” (12)清の顧震濤の「吳門表隱」巻一。

“瑞雲峰, 紫雲峰, 観音峰の三つは, 鮮 やかで向こうが透けて見え, 高く算えてい る。宋代に, 朱勔が採ったものである。後 に, 薰鄥陽の所有となり, そして, 徐氏の 東園に移し置かれた。瑞雲峰は, 乾隆四十 四年 (1779) に, 織造府（官営織物工場） の西の行宮の内に移された。”

(13) 清の姜紹書の『韻石齋筆談』巻上, 瑞 雲峰。

“震澤（太湖）の洞庭山の篦で, 奇石が 採れる。宣和年間に, 朱洏は, 刍山で, 神 運峰を採った。それは, 幅が百圍, 高さが 六伆あった。中国の東南の人民を患わせ, 汁京 (開封) に運ばれ, 艮獄の第一の峰と なった。今, 姑蘇（蘇州）の徐氏の庭園に ある瑞雲峰も, 神運峰と肩を並べるほどの ものである。峰が算え (峯變秀抜), 険し くで (篇寡), 中空となっていて (嵌空), 青々としていて光沢があり (蒼潤), 鋭く て(嶙峋), 樹林の中より抜きん出ている かのよう (箃立林表) である。はじめ, 王 文恪（王陶（1020-1080）の別荘にあった。 後に, 太僕（官名）であった徐君の所有と なった。徐君は, 呉門 (蘇州) に隠棲のた めの邸を作ったとき，この石を移し置いた。 船を連ねて, この石を乗せ運んだ。すぐに,
湖の真ん中に至ったが, その時, 風と波が 激しく, 船は覆り, 石は沈んでしまった。 この時, 波は冷たく遙かに広がり, 月の光 が水面に摇れていた。柔らかい白絹のよう な雪が積もり, その上に, 雲の影が映って いた。不気味な淵の底から, 休むことなく 波を湧き起こしていた大魚が, 波の真ん中 より飛び出して, 清らかに骨のような大石 になったかと思えるようなその石が, 今, 荒波打ち寄せる淵のどこにあるのか, 誰に もわからなかった。人は, 崖の上に立ち, 水中を親いたが，どうにもならなかった。 徐君は, もとより, 李德裕 $(787-849)$ の ような怪石趣味があり，怪石をたくさん持っ ていたのだが, 今は, どうしてもその石を 失いたくなかった。漁師を広く集めて, 広 い湖の中，その石を探させた。まるで，海 女が真珠を採っているかのようでもあり， また, 船頭が, 湖中に消えた剣を探してい るかのようでもあった。突然，大波の中に， 高く険しい影が現われたのを知った。ほん やりとして,よくわからなかった。そこで, 大きな筏を組み, 起重機のようなものを作 り, 千人の人夫を使って，それを水辺に急 いで引き上げさせた。大きな岩のように安 定していた。が, 求めていた石ではなかっ た。そして, 上く見てみると, それは, 求 めていた石の台座だった。徐君は, その石 が是非とも欲しくなった。それがため, 様々 な手段を，あまねく求めた，竜宮に冥揬 (意味不明)し, 漁師は, 深い淵に再びも どり，その石を探した。谷を超え，䈔を穿つ た。足の指がしばしば裂けてしまうほどの 苦労をした。そして, 長い網を使って, 石 を引き上げた。石は, 大龜が, 山を背負っ ているかのようにして, 水面を横切った。 それは, まさに, 求めていた石だった。そ こではじめて，運がよく，また，確かに何 かの縁というものがあることを知った。瑞 雲峯も台座も失われなかった。それらが, 再びもとにもどったのは, 偶然ではないの

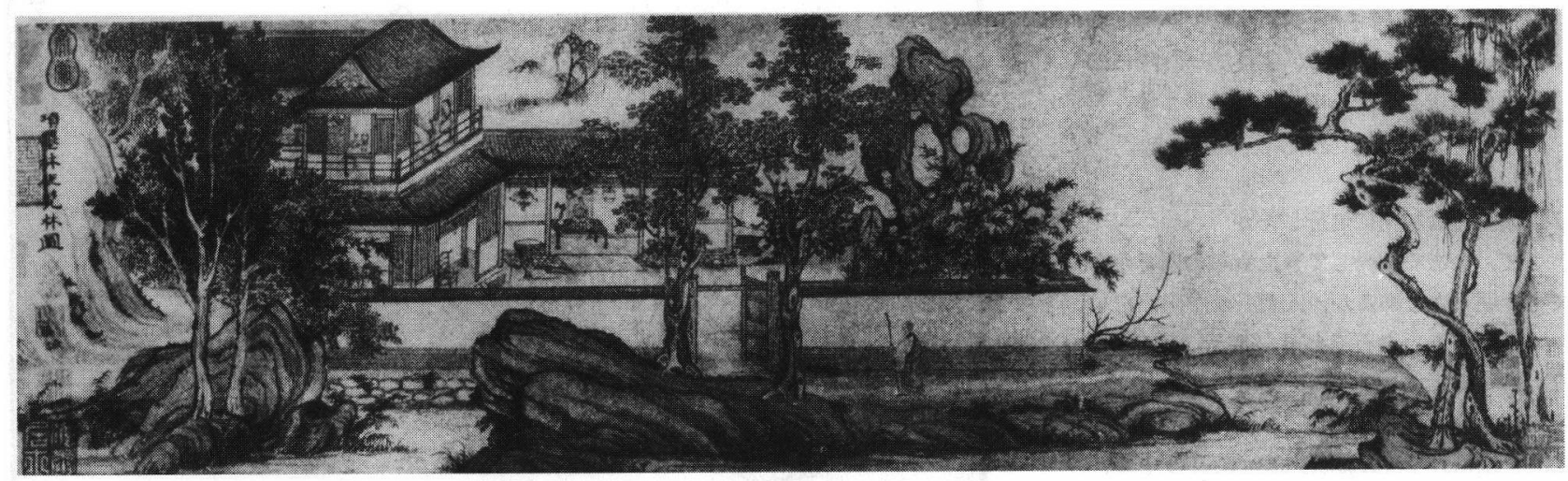

図 8 ) 明の項元沛 (d. 1590) の『梵林図」。 太湖石と思われる怪石を用いた庭園を描いた代表的な作品である。 
である。”

(14) 宋の周密の『癸辛雜識』前集, 吳興園 煵。

“沈尚書の南園。沈徳和（沈介（ca.113 0)）尚書の庭園は, 南の城壁に沿って, 百 餘㑼 (約 $56625 \mathrm{~m}^{2}$ ) ほどの広さがあった。 果樹がたいへん多く, 特に, 林樆が多かっ た。庭園の中には, 聚芝堂, 蔵書室があり, 聚芝堂の前には, 十畧 (約 $5663 \mathrm{~m}^{2}$ ) ほどの 広さの大池が穿たれていた。池中には，小 山があって, 蓬莱と呼ばれていた。池の南 には, 三つの大きな太湖石が立てられてい た。それぞれの高さは, 数丈 ( 5 丈は約 15 . $4 \mathrm{~m}$ ) あり, 高く惩え, 光沢があり, 険し くて, 当時有名だった。後に, 賈師憲（賈 似道 (1213-1275)) が，その石を得ようと， 人夫を数百人集め, 大木で大きな台を作り, 大きな綱を掛け, 城壁から吊り出し, 並べ た二艚の船に乗せて, 谷や川を渡り, その 石を紹興にあった彼の邸に運んだ。この時, およそ数人の人夫を失った。さらにその後, 賈師憲が官職に破れた時, 彼の家の色々な 物が投売にかけられたが, その時, その石 だけが，泥中に残った。たまたま，王子才 が, その石に興味を持ち, 役所に払い下げ てくれるようにたのんだ。そして, 彼は, 職人を雇い, その石を(彼の邸に) 移し置 いた。しかし，彼は，その費用を支払わな かった。そのため, 暫らくもたたないうち に，その石は，盗み売られたと非難するも のがあった。そこで, 役所は, ほとんど半 年もの間, 彼を捕らえ留置した。この時, 彼が支払った金額は，石の費用の十倍になっ た。その果てに, 役所は, さらに, 石を彼 から取り上げて，もとの所へもどした。ま さに,これは, 石の崇りである。”

“韓氏園。南にある関所から, 二里（約 $1.1 \mathrm{~km})$ のところにある。かつては, 平原 郡王であった韓捤昌（1151－1207）の一族 のものであったが, 後に, 我が家の所有と なった。この庭園を, 南郭暚, 城南讀書堂, 萬松関と名付けた。太湖石の三つの峯があ り，それぞれ高さが，数十尺（50 尺は約 $15.4 \mathrm{~m})$ あった。韓氏が全盛だった時に, 多くの人夫達を使って，そこに移し置いた ものであった。”

\section{7. 太湖石は如何に流行したか}

さて，今まで紹介してきた資料の内容から でも，明らかであるが，太湖石が中国でたい へん人気があった石であったことには問題は ない。この点は, さらに, 例えば, 次のよう な資料からも明らかである。

・『園治』や『五雜組』は, 怪石の中で, 太湖石を第一に取り上げている。

・『漁陽公石譜』によれば, 中国の北方で
は太湖石が, 南方では靈璧石が流行して いるが, 南北合わせれば, 太湖石が一番 であるという ${ }^{21}$

『研北雜志』も同様に, 太湖石が一番で 山石（おそらく靈璧石のこと）がその次 であるとする22

・白居易は, 『太湖石記』（7-3) で，太 湖石が一番で, 羅浮石と天竺石がその次 であるとする。

『華陽宮記事』は, 北宋の微宗の艮嵪の 造成の記事として, 太湖石, 靈璧石を集 めたことを記しているが, 太湖石が先ず 一番にあげられている23)

しかしながら,太湖石が, 中国で最も愛好 された石であったとは言い切れないようであ る。というのは, 次のような文献資料がある からである。

『長物志』によれば, 霝壁石が一番で, 英石が二番であるとされ，太湖石は三番 めにあげられている゙

『洞天清禄集』は,八つの代表的な怪石 をあげるが, 一番が靈璧石で，太湖石は 八番めである ${ }^{25)}$ 。また, 太湖石に色をつ けて靈璧石の偽物をつくっていたという $(7-(1)) 。$

『雲林石譜」は, 多くの怪石を紹介して いるが, その一番めが孁璧石で, 太湖 石は四番めである。

· 宋の張淏（ca.1180-1250）の『艮獄記』 では，艮獄造成の石として，靈璧石，太 湖石といった記し方をしている ${ }^{25)}$ 。 ·宋の程大昌 (1123-1195) の『演繁露』 も, 当時の怪石の流行を述べているが, 霝璧石, 太湖石といった記し方をしてい $3^{27)}$ 。

以上より，今日では，あまり知られていな
いようだが，太湖石に勝るとも劣らぬ石とし て，靈壁石という石があったことが理解され よう。ということは, 太湖石が今日のような 庭園における絶対的な地位を持つようになっ たのは，比較的時代が浅いことであるのかも しれない。ちなみに, 靈璧石とは次のような 石である(図9，10）。

(1) 宋の趙希鵠の『洞天清禄集』怪石辯。

“靈璧石は, 綘州 (宿州 (安微省) の誤 りか）の靈璧縣で採れる。この石は, 山中 の谷間に転がっているのではなく, 地中を 深く掘ると, はじめて出てくる。漆のよう な色をしている。なかには,玉のように細

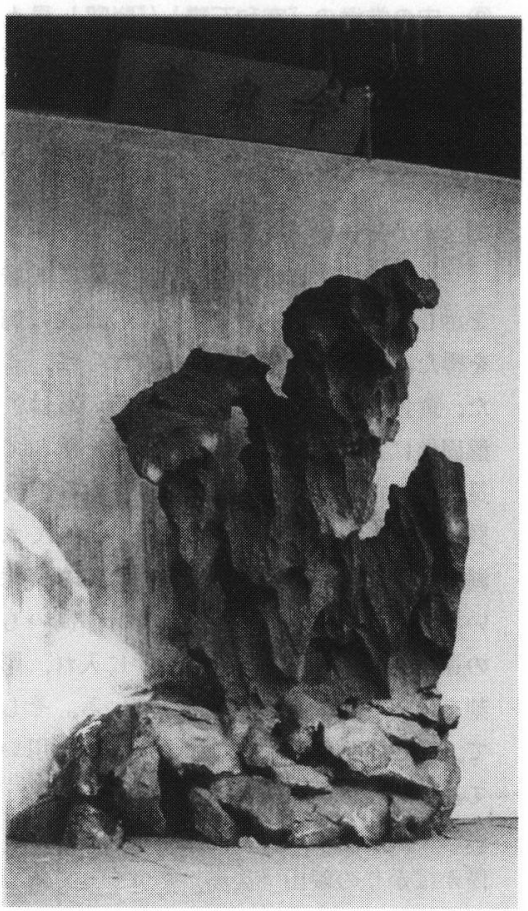

図9）靈璧石。

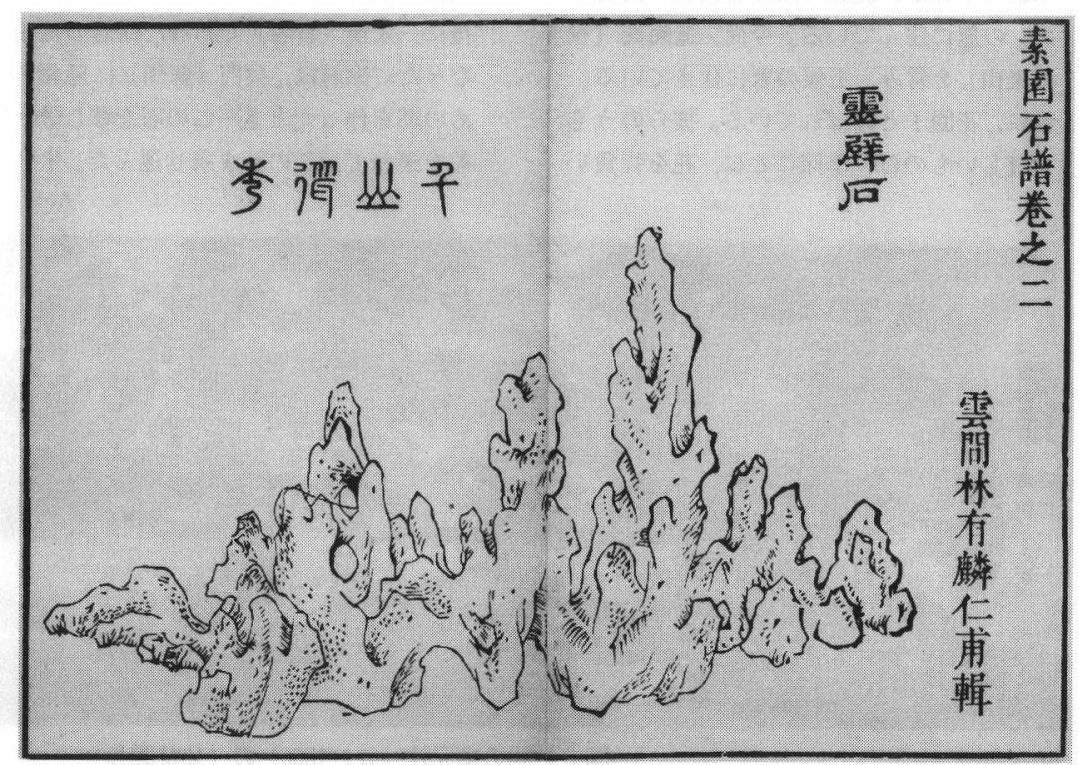

図10）靈壁石図。(『素園石譜』巻二。) 
く白い筋目が入っているものもある。しか るに, 峯のように貨えたところや, 穴はな い。よいものは, 蓮の花のようであったり, 横たわる牛のようであったり, どくろを巻 いた龍のようであったりする。吒くと, 黄 金や珠玉のように澄んだよい調子に響く。 よく切れる刃物で削っても, 大方びくとも しない。この石は, 香を吸収する性質があ る。書斎のなかに置けば, 香の煙が, 一日 中石のまわりにかかって, 散ることはない。 峯のように䇤えたところがあるものを選ん ではいけない。(偽物が多いからである。) 偽物の多くは, 太湖石に色を付けて作った ものである。思うに，太湖石も吒くと微か にではあるが,(靈壁石のように, ) 響く。

また（靈璧石のように, ) 白い筋目が入っ ている。然るに, 太湖石は, 上く切れる刃 物で削ると粉になってしまう（ので，区別 できるのである。）"

また, 中国の至る所に, 太湖石の庭園があっ たとはいいがたいようである。次のような資 料も見落としてはならないだろう。

・『園治』は,『雲林石譜』を引きながら, 中国のいたるところによい庭石があるこ とを述べている ${ }^{2)}$ 。実際, 「雲林石譜』 には, 百十六種もの石が記されている。 太湖石は, その四番めにあげられた石で ある。

『五雜組』によれば, 福建では太湖石は 入手し難いため, 代わりに, 地元の白沙 渓というところの北方の山の上で取れる 石が, よく用いられていたといゔ。 明の陸深 $(1477$ - 1544) の『春雨堂随筆』 によれば, 武康縣の人々は, 地元に産す る武康石を用いて假山をつくっていたと いう ${ }^{(0)}$ 。

明の王世貞 $(1526-1590)$ の『遊金陵諸 園記」の記す金陵（今の江蘇省南京）の 庭園には, 明確に太湖石を記すものはな く,むしろ, 錦川石や武康石を用いた假 山が記されている゙11。

『陶庵夢憶』には, 山水画のような趣が
あるすぐれた螺山石の假山が記されてい る20

以上により,太湖石が, 実際に, 中国全土 に渡って, 広く一般的に用いられていたとは 言い切れないようである。さらには，

·宋の陸游（1125-1210）は，空の前に小 さな土の假山をつくったことを記してい る3)。

·白居易は, 終南山（長安の南にある山） を思わせる土の假山が知人の家にあった ことを記している゙1)。

•唐の杜甫 $(712-770)$ は, 堂の前に, 土 の假山をつくったことを記している゙5)。

以上を考えるに, 今日, 中国庭園の假山と いえば, 太湖石の假山が思い出されるが, か つては，必ずしもそうではなかったようであ る(図 11)。ということは, あるいは,太湖 石の実際の流行使用所有は, その大人気とは 裹腹に, 明末清初以前においては, 特権階級 や一部の熱狂的愛好者や特定の地域の人々に 限られていたのかもしれない。

最後に, 太湖石趣味で有名な白居易の庭園 にも触れておきたい。というのは, 今日に残 り伝わる詩文から察するに, 彼の時代, 彼ほ どの太湖石趣味をもっていた人物はそれほど いなかったと考えられるので, 白居易の庭園 を見れば, 当時の太湖石の庭園が大方想像さ れると考えるからである。

先ず, 邸宅の場所と広さに関しては,

『池上篇并序』によれば, 彼は, 洛陽城 内東南に位置する履道里の西北隅に広さ 17 畧 (約 $\left.9866 \mathrm{~m}^{2}\right)$ の邸宅をもっていた といゔ ${ }^{36}$ 。その三分の一が建物であった というから,残りの三分の二の多くが庭 園として様々に利用されていたと考えて よかろう。

持っていた太湖石の数に関しては,

・『旧唐書』に引く『池上篇」によれば, 五個である

・『池上作』と題する師によれば, 四個で ある ${ }^{38)}$ 。

いずれにせよ, 太湖石趣味で有名だったわ
りには，僅かに数個持っていたに過ぎなかっ たようである。

その太湖石の大きさに関しては,

・『太湖石』と題する詩に記された太湖石 の高さは八九尺（約 2.5-2.8m）である。

・雙石』(7-2) と題する詩には, 明 らかに彼自身のものであると見なせる二 つの太湖石の特徴が記されているが, そ の高い方の高さでも, 数尺（五尺は約 $1.6 \mathrm{~m})$ に過ぎない。

ということは, 白居易の庭園は, あるいは, 当時の一般的な庭園は, 今日我々が理解して いるような太湖石により複雑に構成された中 国庭園とは異なる様式をもっていた可能性が あるのではなかろうか。

ところで, 白居易は, 太湖石を如何に解釈 していたのであろうか。この点に関して，太 湖石に関する白居易の代表的な作品で, 彼が 自ら所有した太湖石に関する『雙石』と題す る詩, ならびに, 当時太湖石の収集家として 最も有名だった牛僧瓀 $(779-847)$ の太湖石 趣味を述べながら太湖石のすばらしさを記し た『太湖石記』を，以下に訳出しておきたい。 また, 牛僧獳自信が太湖石を如何に解釈して いたかを記す詩, すなわち牛僧瓀が自ら太湖 石を主題に記した詩もあるので,ここに併せ て訳出しておく。

\section{(2) 唐の白居易の『雙石」(『全唐詩』巻四} 百四十四)

“青い二つの石がある。その形状は醜怪 きわまる。普通では使いものにならないの で,人々は嫌って採らなかった。天地が開 けはじめた時できたもので, 長い間水辺に うち捨てられていた。それが洞庭湖の入江 で採れ，ある日突然私のものになったので ある。郡の役所に運び込まれ, 泥が洗い落 とされた。煙の跡が厚くついているかのよ うに穴は黒く, 隙間には青い苔が厚く生え ている。根元は年老いた龍がどくろを巻い ているかのようで, 頂は古びた剣のごとく 尖っている。天上より落ちてきたものかと ふと思え, この世のものとは思えない。そ

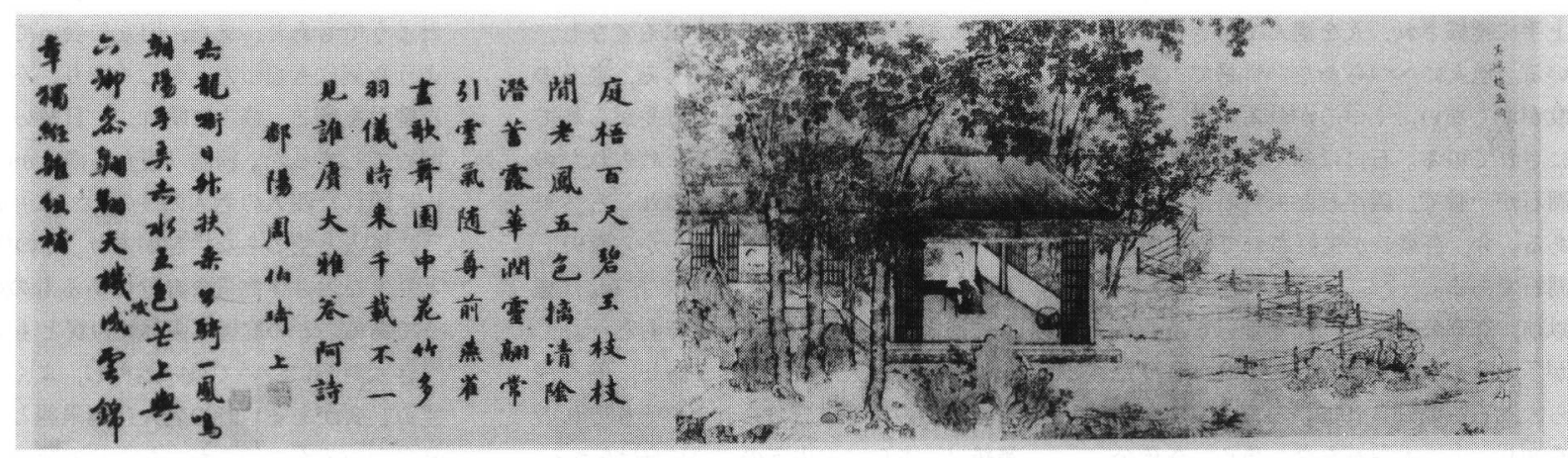

図11）元の趙孟煩（1254-1322）の『百尺梧桐軒図」。 太湖石の庭園とは異なる趣を有する庭園が描かれている。 
の一つは高く聯え, その高さは数尺（五尺 は約 $1.6 \mathrm{~m} ）$ あり，私の琴を支えるのによ い。もう一つは深く窪んでいて, 一斗ほど 入れられ，酒を貯えるによい。五絃の琴を 左の石に寄せ掛け，杯を一つ右の石の上に 置いた。窪んだ石の酒樽は酌めども尽きな い。私はもうとっくに酔い潰れてしまった。 人には皆好きなものがある。物もそれを持 つにふさわしい人を求めている。私は歳を とり若者の仲間には入れてもらえなくなっ たことを漸く感じだした。そこで振り返っ て二つの石に問うてみた。私のような年寄 りと一緒に居れるかどうかと。石は何も答 えることは出来ないけれど, 私を友と認め てくれた。そして, 二つの石と私は友となっ たのである。”

(3) 唐の白居易の「太湖石記】(唐文粋】 巻七十一)

“昔の達人には皆爱好するものがあった。 玄晏先生 (晋の皇甫䍀) は書を, 秋康 (晋 の竹林の七賢人の一人) は琴を, 靖節先生 (晋の陶㴰) は酒を爱好された。今, 丞相 (官名)であられる奇章公（唐の牛僧瓀） は，石を愛好されている。石には文字がな く, 音色がなく, 匂いもなく, 味もない。 書, 琴, 酒とは異なるものである。それで も奇章公が石を爱好されているのはなぜだ ろうか。皆, これを不思議に思っているが, 実は私だけがその理由を知っている。ある 時, 旧友である李生があることを約束した 時に、「気に入りさえすれば，使いみちは 多いものである（気に入りさえすれば，あ とは理屈などないのである。」といったこ とがある。まさにこれである。奇章公が石 を愛好されている理由は，(ただ理屈なく） 石が気に入ったからなのである。

奇章公は司徒（官名）になられ，河洛 （黄河と洛水の流域の地）を治められてい る。邸をつくられたが, 珍しいものを集め られたりされていない。自らの仕事に専念 され䩀沢はされていない。ただ（洛陽）城 の東方に邸を一つ建てられ, 城の南方に別 荘を一つ建てられているだけである。建物 を上手に補修され，人を選んで付き合われ ている。他人にへつらわない性格で, 常に 無䭾がすくない。くつろがれる時は，石を 友にされている。石には多くの種類がある。 太湖石が一番で，羅浮石と天竺石がその次 である。今, 奇章公が愛好されているのは, 太湖石である。

以前, 奇章公の部下に江湖地方を治める 者が多かった。彼らは, 奇章公がただひた すら太湖石を愛好されているばかりである のを知り, 広く太湖石を探し集め, 奇章公 に献上したのである。四五年の間に太湖石 はるいるいと集まった。奇章公は, 太湖石
にはもっぱら目がなかった。太湖石は邸と 別荘に並べ置かれた。実に多くの太湖石が 集められたものである。

その形は実に様々である。どこか不思議 な小山か鮮やかな雲のように，渦を巻き捻 れ高く算えているようなものがある。仙人 や道人のように，端正で簃格に䍈えている ようなものがある。珪瓚（酒器）のように, 黒くて光沢があり尖っているものもある。 武器のように, 角が鋭く尖ったものもある。 さらには, 龍や鳳凰が伏したり動いたり飛 んだり跳ねたりしているようなものもある。 鬼や獣が歩いたり走ったり何かを掴んでい たり闘っていたりしているようなものもあ る。風が吹き荒れ雨に暗む夕べに，洞穴が 開いて雲を吸ったり雷を吐いたりしている ような高く秋えて恐ろしいものもある。篒 が晴れて景色の麗しい夜明けに, 切り立つ 崖に雲がたなびき, 山に立ち籠める蒸気が 晴れて, 美しい木々の緑が映えているよう な,のどかで親しみを感じさせるものもあ る。とにかく，朝に夕に太湖石を見るのた が, その様をいいあてることはできないも のである。一言でいえば，三山五獄や数多 くの洞笜や渓䜪小さくなって，その中に 集まっているかのようである。極めて高い 山が拳ぐらいに小さくなっており，一目で 千里を見通すことが，座ったままでできる ような気にさせられる。それ故, 太湖石を 奇章公は気に入られたにちがいない。

いつも私は奇章公と共に, 太湖石を近く でよく見ている。色々と考えてみるに，万 物を創造した神が意識的に太湖石をつくっ たとは思えない。あるいは混沌としたもの が固まって偶然に出来上がったのではなか ろうか。そして, 出来上がって以来幾千万 年もの間に, 太湖の入江にたまったり太湖 の底に沈んだりしたのであろう。高いもの は数仞（五仞は約 $10.9 \mathrm{~m}$ ）ほどもあり, 重 いものは千鈞（約 17.9t.）ほどもある。ひ とたび世に出て以来, 太湖石はたちまちに 流行し，実にすぐれて珍しいさまが奇章公 の目にとまり気に入られたのである。奇章 公は太湖石を客や友人のようにもてなし, 賢人や哲人に対するように親しみ，宝玉の ように尊び，子や孫のように可爱がられて おられる。奇章公が太湖石を求められたの か，あるいは太湖石が奇章公のところへ来 るのを望んだのか, どちらかわからない。 どちらか必ずわけがあるはずである。(思 うに，きっとそのどちらともであろう。)

太湖石には大小 (優劣) があり，甲乙丙 丁の四つの等級に分けられる。それぞれの 等級は, さらに上中下の三つに分けられる。 奇章公の太湖石のそれぞれの襄面に，その 等級を記したところ, 甲の上, 丙の中, 乙
の下となった。

ああ, 太湖石上, 何百何千年と経てば世 に流れ所を変え，あるものは残りあるもの は失われ，そして誰もおまえの存在に気づ かなくなるだろう。後の世の私と同じ趣味 を持つ人々に太湖石を見せ，この文章を読 ませ, 奇章公が太湖石を愛好されているわ けを伝えたいものである。曾昌三年 (843) 五月丁丑の日に記す。”

\section{(4) 唐の牛僧隭の「李蘇州遣太湖石奇状絶} 倫因題二十韻奉呈夢得樂天」(「全唐詩】 巻四百六十六)

“混沌としていたものが, 何時固まって 石になったのか分からない。中空になった 石が今ここにある。高く伸上がったり低く うずくまっているさまは, あたかも龍と虎 が闘っているようでもあり, また，ものが 破れたようで常なら廆神さえも 驚くであろう。雨を帯びると清い水が溜り, 軽く吒くと砕けた玉のように響く。矛先の ように鋭く尖ったところがあり，また，系 が絡まったようなところもある。水辺でた いへん清らかに摇らぎ，松にもたれて静か に休んでいるようである。全身鱗に覆われ ているようでもあり，穴を通して洞天（仙 境）がよく見えるようでもある。醜い瘤は， まるで顎の下の垂れ肉のようで, 深い寉み は，水牛の角で作った杯のようでもある。 雷や風がまさに起きようとしているかのよ うであり, 辺りが薄暗くなっていくかのよ うでもある。ちと寒い朝に口をつぐんで震 えているような大きな石が, いくつか横た わっている。地神さえもが心配しそうなく らい, 崩れてしまいそうで不安定な感じが する。姑蘇（蘇州）の役人が珍重していた この石には, 可愛いような憎いような趣が ある。大魚に襲われる危険をも顧みず，太 湖の底よりこの石は採られた。そして, 千 里の道程をものともせずに運ばれた。この 石を, 初めて池の辺に置いてみると, 黄金 や珠玉も色褪せてしまった。一目見たとき， 不安な気持ちになったが, よく見てみて, ようやく安心した。すばらしい友人に出会っ たようでもあり，また，旧友に会っている ような気にもなった。楽しくなり, 不思議 な魔力を感じ, 悩みは晴れ, 二日酔いなど 醒めてしまった。綺皓（秦から漢にかけて， 山に隐れた四人の老人のうちの一人）のよ うに俗人と交わらない趣があり, その様は, とりもなおさず高貴な身分にあるもののよ うである。この庭園 (園林) の筫ともいう べき太湖石について思い巡らし, よく理解 する必要がある。詩の名人に劉禹錫と白居 易とがいるが, 彼らが, なんじ太湖石のた めに，しばしば詩を作ってくれることであ ろう。” 


\section{おわりに}

太湖石は，太湖（江蘇，浙江両省にわたる 湖で, 洞庭湖とも呼ばれる)に産する石灰岩 である。産地としては, 洞庭西山と呼ばれる 島の消夏湾と雨山が特に有名である。唐代, 特に白居易のころ，すなわち，八世紀後半か ら九世紀前半頃より，太湖石という名称を以 て知識人の間で流行しはじめ, 宋の宣和 (11 19-1125）年間に良䁨という假山が造られた ころより，広く流行するに至ったようである。 太湖石は，その波の走り具合 (透), 穴が開 いていて向こうが透けて見えるところ (漏)， 細く高く䇤えているようなところ（瘦）が, 特に，爱好されたようである。そして，太湖 石が, 中国の怪石趣味流行の旁引役を務めた 名石であったことには問題はない。

しかしながら, 中国には，太湖石の他にも， それぞれの土地に様々な名石があった。たと えば，露壁石がその筆頭にあげられよう。ま た，土の假山の記録も見られる。さらには， 太湖石趣味の代表ともいえる白居易の庭園も, 太湖石が僅かに数個据えられた程度のもので あったらしい。これらの点を考えるに, 今日 遺跡の残らない明末清初 (十七世紀頃) 以前 においての中国庭園は，今日の太湖石に代表 されるような庭園遺構のみをもってしたとこ ろで, 理解され得るものであるとは限らない ようである。

では，太湖石は今日なぜ過剩にといっても よいほど，もてはやされているのだろうか。 この点を明らかにするためには, 清初以降の 文献資料，ならびに，太湖石で知られる江南 地方ばかりではなく, それ以外の地方の庭園 の状況をさらに検討してみる必要があるだろ う。

註：

1) 日本の造園史の研究者による太湖石に関 する専論としては, 次の論文がある程度 である。

a ）田治六郎：「太湖石」, 『造園雑誌』, 11 巻 1 号 1948 pp. 16-20 次の文献は, タイトルは太湖石に関す るものだが, 実際は, 中国の怪石趣味 をまとめたものである。

b ) 村松伸：「太湖石のフェティシズム」, 『現代思潮』特集タオイズム $1991 \mathrm{pp}$. $84-101$

次の写真集の太湖石の写真は有用で ある。

c）吉河功：〔中国江南の名園」, 東京; グラフィック社 1990

2 ）日本庭園における中国庭園の直接の影響 を深く検討した専門の論文を，浅学のた めかもしれないが、筆者はまったくしら
ない。

3 ) この点を指摘する論文として, 次は注目 に值する。

a）田中淡：「中国造園史に扔ける初期的 風格と江南庭園遺構」、東方学報」第 62 冊, 京都; 京都大学人文科学研究 所 1990 pp. 125-164 また，十四世紀までの中国，韓国，日 本の庭園の共通性を述べる次の論文も 見落としてはなるまい。

b ）鄭朣旿：「韓日伝統庭園様式の比較研 究」『韓国庭苑学会誌』第 1 巻第 1 号 ソウル；韓国庭苑学会 1982 pp.4162

4 ）田中淡：「都市の中の理想郷」『庭園と 音楽」(朝日百科世界の歴史 95), 東京： 朝日新聞 1990 pp. E590-591

5 ) 白居易の詩に関しては次を参照。 (国訳漢文大成第 9 巻続文学部第 2 輯) 白 楽天詩集白楽天詩後集，東京; 国民文庫 刊行会 1941

6 ) 中田勇次郎：『中田勇次郎著作集』第 9 巻, 東京; 二玄社 1986 pp. 229-238

7 ) 中田勇次郎：『中田勇次郎著作集』第 8 卷, 東京; 二玄社 1986 pp. 69-129

8 ) 入谷仙介：『高啓』(中国詩人選集二集 第十巻), 東京; 岩波書店 1990 pp.8186

9 ) 入矢義高（編）：『近世随筆集』(中国 古典文学大系 55), 東京; 平凡社 1971 pp. 103-107

10）中田勇次郎：6）pp. 241-248

11）松枝茂夫：『陶庵夢憶』(岩波文庫), 東 京; 岩波書店 1991

12）中田勇次郎：6 ) pp. 46-47

13）吉河功： $1-$ c ) p. 145

14）田治六郎：1- a )

15）【造園修景大事典」, 京都; 同朋舎出版 1980 巻 5 pp. 134-135 たいこせき

16） a )『五雜組」巻三：“至宋宣和時。朱 竻童貫以花石娱人主意。‥石自此重矣。” b ）『癸辛雜識』前集。假山：“前世畳 石爲山未見顕著者至宣和艮岳始興大役...”

17)『子瞻喜雨亭北隋仁壽宮中怪石」(『樂城 集」巻二。）：“仁壽宮中穭穀生。太湖 蒼石草間横。…”

18）艮䓂に関しては，現在のところ以下の二 つが最も詳しい論考のようである。

a ) Kuhn, Dieter : Zur Entstehungsgeschichte des kaiserlichen Felsenparks Genyue in der Hauptstadt Kaifeng am Vorabend des Untergangs der Nördlichen Song Dynastie, Heidelberg 1987

b ) Hargett, James M: “Huizong's Magic Marchmount : the Genyue
Pleasure Park of Kaifeng " , in Monumenta Serica Vol. 38 1988-1989 pp. $1-48$

19）宣和四年（1122）に艮孰が一通り完成し たことは，次の資料によっても理解され よう。李質の『艮獄賦」序：“宣和四年 歳在壬寅夏五月朔艮啍告成命小臣質恭請 作古賦...”

20『陶庵夢憶』巻二。花石綱遺石。にも, 瑞雲峰に関すると思われ記載がある点は, すでに田中 3 - a ) p. 147 が指摘すると ころである。

21）【漁陽公石譜』(『説郛』巻十六。）“たい てい, 北方の人は太湖石を, 南方の人は 靈璧石を遠方よりの珍品として尊んでい る。もし，あわせれば，太湖石が第一で， 山石（靈壁石）はその次である。”

22）『研北雜誌』巻下。“鮮于伯機（鮮于樞 (1259-1301) は, 太湖石を第一とし, 山 石（靈璧石か）はその次といっている。” 思うに, 鮮于樞は, 元代の漁陽（現在 の北京の東北）の人で, 当時有名な美術 の鑑定家である。あるいは，21）の『漁 陽公石譜」の漁陽公とは彼のことかもし れない。

23）『華陽宮記事』：“築岡阜高千餘仞。増 以太湖露壁之石。”

24） a ）『長物志』巻三。品石。“石といえ ば、靈璧石が一番で, 英石がこれに次ぐ。 しかるに,この二つの石は値段が極めて 高く, 買い入れるのが頗るむずかしい。” 思うに, 露璧石, 英石, 太湖石は，そ れぞれかなりの趣があった石であったら しい。『與郡志』や『太湖石志」で知ら れる范成大は，それぞれの名石を持って いたことが次の資料により知られる。

b )【太平清話』“范石湖（范成大）の小 峨嵋は靈壁石である。煙江疊嶂は太湖石 である。天柱峯は英石である。皆彼の趣 味に適っている。”

25【洞天清禄集』怪石辯。“怪石には，霝 璧石, 英石, 道石, 融石, 川石, 桂川石, 邵石，太湖石などがあり，他にもたくさ んある。”

26）張淏の『艮獄記』：“計會宦者以缺者。 大率露璧太湖諸石。”

27）【演繁露】巻三。怪石。“『書経」禹貢に よれば, 青州の献上品に鉛と松と怪石が あったという。この怪石は飾り物であり， 献上品としては不適当ではないかと考え ている者がある。私が思うには，そのよ うに解釈するのは間違っている。ここに いう怪 (怪石の怪) とは，今愛好されて いる靃壁石や太湖石のように，中空になっ ていて，鮮やかに美しく，鑑賞するに足 るものという意味ではない。形や光沢が 
石に似てはいるが石ではないという意味 で，怪というのである。怪は，異なると いう意味なのである。”

28）「園冶」巻三。五選石。：“夫茸園戋假 山。處處有好事。處處有石塊。但不得其 人。…曾見宋杜綰石譜。何處無石。”

29）「五雜組」巻三。：“閩中白沙溪北有温 泉焉。地名湯院。山上出石。…閩人園中 常以此代太湖。”

30)『春雨堂随筆」：“武康石。色黒而潤。 文如波浪。人家園池礐假山。以此爲奇。”

31）【遊金陵諸園記」：“徐九宅園。…峰石 皆錦川武康。”

32）『陶庵夢憶」巻一。金乳生草花。：“欄 前以蝠山石累山披數摺。有畫意。”

33）『窗前作小土山蓻蘭及王䇥最後得香百合 併種之戯作』(『劍南詩稿」巻二十九。)

34）『累土山』(『全唐詩」巻四百三十八。和
元八侍御升平新居四絶句。）：“堆土漸 高山意出。終南移入戸庭間。”

35）「天璸初南曹小司寇舅於我太夫人堂下累 土爲山一實…」(『全唐詩」巻二百二十四。)

36）【池上篇并序』(『全唐詩』巻四百六十一。) : “都城風土水之勝。在東南偏。東南之 勝。在履道里。里之勝在西北隅。西開北 垣第一第。即白氏叟樂天退老之地。地方 十七畧。屋室三之一。水五之一。竹九之 一。”

37）『旧唐書」巻百六十六に引く『池上篇」: “罷蘇州刺史時。得太湖石五。”

38）『池上作】(『全唐詩」巻四百五十三。）： “太湖四石青岑岑。”

\section{挿図出典：}

1 )『素園石譜」巻二。

2 ) 『蘇州府志』太湖全図。
3 ）孫位の『七賢図』/『中国美術全集」絵 画編二, 隋唐五代絵画, 北京 ; 新華書店 1984 図 31。

4 )『素園石譜」巻四。宣和六十五石。神運 明功。敷慶萬壽。

5 ) 瑞雲峰／吉河功 $1-\mathrm{c}$ ) p.127

6 ）文嘉等の『合作薬草山房図』/『中国古代 書画図目」3, 北京; 新華書店 1990 p. 119

7 ）文征明の『真賞齋図」／『中国古代書画 図目」1，北京；新華書店 1986 p. 35

8 ）項元汁の『梵林図』／【中国古代書画図 目」7, 北京; 新華書店 1989 p. 51

9 ) 靈璧石/吉河功 $1-$ c ) p. 127

10）『素園石譜」巻二。

11）趙孟北頁の『百尺梧桐軒図」／『中国古代 書画図目」2, 北京; 新華書店 1987 p. 78 (1993.10.13 受付, 1995.1.28 受理)

Summary : The strangely shaped rocks yielded from Lake Tai (Taihu 太湖) in the southern Chinese provinces of Jiangsu 江蘇 and Zhejiang 浙江 are regarded as one of the traditional elements characterizing Chinese gardens. Taihu rocks (jap. Taikoseki 太湖石) started to become popular among scholars during the late 8th to the early 9th century. In the beginning of the 12 th century Taihu rocks met passionate acceptance not only from scholars, but also among the general people.

This paper argues that, however popular the Taihu rocks may have been from the 12th century onwards, it seems that they were still distributed in relatively small numbers. From extant records it seems obvious that they were only put up and displayed in the gardens of a few enthusiasts, some of whom had their residences near Lake Tai, and others being driven by a fanatical interest in this special type of rock to have it transported to distant places. Not surprisingly those who did get those rocks to their faraway homes had strong social power and connections.

The relative scarcity of Taihu rocks in contemporary records and other texts up to the 17th century proves that "traditional" Chinese gardens of that period may probably have looked completely different from what we imagine today. 